\title{
New high-resolution aeromagnetic and radiometric surveys in Finnmark and North Troms: linking anomaly patterns to bedrock geology and structure
}

\author{
Aziz Nasuti' ${ }^{1}$ David Roberts', Marie-Andrée Dumais' ${ }^{1}$ Frode Ofstad', \\ Eija Hyvönen², Alexandros Stampolidis' ${ }^{1}$ \& Alexei Rodionov ${ }^{3}$
}

\author{
${ }^{1}$ Geological Survey of Norway, P.O. Box 6315 Sluppen, 7491 Trondheim, Norway. \\ ${ }^{2}$ Geological Survey of Finland, P.O. Box 96 Betonimiehenkuja 4 FI-02151 Espoo, Finland. \\ $3 A R$ Geoconsulting LTD., 124 Cougar Ridge Dr. SW, Calgary, AB, T3H4X6 Canada
}

E-mail corresponding author (Aziz Nasuti): aziz.nasuti@ngu.no

\begin{abstract}
New high-resolution aeromagnetic data from the Caledonides and Archaean-Palaeoproterozoic crystalline basement of Finnmark and North Troms derived from surveys conducted as part of NGU's MINN programme provide spectacular and confirmatory evidence for the continuation of diverse, Precambrian greenstone belts and granulite terranes beneath the magnetically transparent Caledonian nappes. Complementary airborne radiometric data collected in the same survey contribute to the analytical process and to an evaluation of the mineral potential in the area. Some parts of existing data have also been reprocessed using new techniques and software to reach the same level as the newly acquired data. The new compiled data provide images of the magnetic field at sufficiently high resolution to allow us to examine finer details of the bedrock geology. One of the principal outcomes of the analysis is a picture of the detailed structural fabric of the region provided by images of tilt derivatives of the magnetic field that enhance anomalies. This fabric is an important framework for developing exploration strategies. Patterns and other characteristics of the magnetic field have been used to revise positions of some geological boundaries, especially in poorly exposed areas, and delineate specific domains within northern Norway. Radiometric data have been used to supplement the magnetic interpretations in some cases. In general, there is a good correlation between the radiometric data and magnetic anomaly maps which can be utilised to re-evaluate the geological boundaries. Several such features of interest are discussed. As an example, NW-SE-trending, fault-bounded terranes or belts which extend from Finnmark and Troms through northern Finland, Sweden and Russia can be easily followed on the high-resolution data. In this contribution, all the main geological terranes from the Archaean-Palaeoproterozoic belt to the Caledonian nappes in northern Norway will be discussed in relation to their magnetic patterns and radiometric anomalies.
\end{abstract}

Keywords: Aeromagnetic data, Bedrock geology, Finnmark and Troms, Magnetic anomaly, northern Norway, Radiometric data

Received 26. May 2016 / Accepted 23. August 2016 / Published online 6. September 2016

\section{Introduction}

The Geological Survey of Norway (NGU) has conducted aeromagnetic surveys on the Norwegian mainland and continental shelf since 1959 (Olesen et al., 2010) and up to the present day the entire country has been covered by airborne magnetic data. In the ensuing decades, however, it became necessary to update the data as it was no longer providing adequate detailed information. For example, many of the original aeromagnetic datasets are digitised hand-drawn contours which were not acquired with an accurate navigation system. Consequently, NGU is constantly implementing new surveys and projects to improve the quality of the data and thus replacing vintage data with the newly acquired data. In this regard, NGU initiated a new programme in 2011, Mineral Resources in North Norway (MINN), which is part of Norwegian governmental strategy to further develop the mineral industry in Norway. The goal of this programme is to enhance and complement the existing geological information that is relevant for an assessment

Nasuti, A., Roberts, D., Dumais, M.-A., Ofstad, F., Hyvönen, E., Stampolidis, A. \& Rodionov, A. 2015: New high-resolution aeromagnetic and radiometric surveys in Finnmark and North Troms: linking anomaly patterns to bedrock geology and structure. Norwegian Journal of Geology 95, 217-243. http://dx.doi.org/10.17850/njg95-3-10. 
of the mineral potential of the three northernmost counties. The high-resolution airborne geophysical surveys, both helicopter-borne and fixed wing, are important integral parts of the MINN programme. The improved quality is mainly due to the use of (1) state-ofthe-art instrumentation, (2) real time, differential GPS navigation equipment, (3) a denser line spacing and (4) advanced microlevelling software.

The vintage aeromagnetic data of the northernmost part of the Norwegian mainland were acquired during the period 1959-1975. At that time flight altitudes and directions, and line-spacings of the aeromagnetic surveys, varied widely. Depending on the topographical conditions of the area, the flight altitudes varied from $150 \mathrm{~m}$ for areas with relatively gentle topography to 800-1500 m a.s.l in rugged terrains (Åm, 1975; Olesen et al., 2010). These data were able to provide a regionalscale interpretation of the geological features and settings of northern Norway. For example, the ArchaeanPalaeoprotrozoic Fennoscandian Shield to the east was clearly distinguished by its strongly magnetised rocks. In contrast, to the west the overlying Caledonian fold belt of metamorphosed Neoproterozoic to Silurian rocks is practically nonmagnetic except for some ironore formations and also the prominent ultramaficmafic complex of the Seiland Igneous Province (Åm, 1975). Despite the valuable general information extracted from these data, we were not able to use it to facilitate detailed geological mapping. For this reason, many important geological features, such as faults, shear zones and dykes, were not readily resolved by these data. In this contribution we present new highresolution aeromagnetic and radiometric compilations, and discuss and interpret some of the major anomalies which have a bearing on possible modifications of the existing geological maps. The new high-resolution data have proved especially beneficial in interpretation of the concealed geology and structures in the vast, largely unexposed terrain of Finnmarksvidda. In addition, we now have a better understanding of the hidden geology and structural features that are easy to trace from the exposed shield areas and beneath the comparatively thin Caledonian nappes, in some cases linking with correlative rock complexes in tectonic windows.

\section{Geology of Finnmark and north Troms}

The bedrock geology of northern Norway (Fig. 1) is dominated by rock complexes of Precambrian to Early Palaeozoic age, a large part of which has been involved to varying extent in the Caledonian orogeny. In general, there is a basic two-fold division into the Caledonides sensu stricto and a mid-crustal continental lithospheric basement comprising autochthonous crystalline complexes that range in age from Neoarchaean to Late Palaeoproterozoic and form the northern margin of the Fennoscandian Shield (Fig. 1; Gaál et al., 1989; Daly et al., 2006). These older Precambrian rocks occur mainly in eastern Finnmark and western Troms, and some are either affected locally by Caledonian deformation or incorporated as thrust slices in the Caledonian nappes (Fig. 1).

The Archaean-Palaeoproterozoic complexes are perhaps best exposed in southeastern Finnmark and occur in several, NW-SE-trending, fault-bounded terranes or belts which extend through northern Finland into the Kola Peninsula and Belomorian province of Northwest Russia. These various terranes together constitute the polyphasally deformed LaplandKola Orogen (Fig. 2), bordered across major suture zones (now ductile shear zones) to the northeast and southwest, respectively, by the Murmansk and Karelian cratons. The northeasternmost belt of Archaean rocks exposed in Finnmark is the Sørvaranger-Kola Terrane (SKT) (Fig. 2; Dobrzhinetskaya et al., 1995), south of Varangerfjorden, with zircon ages on orthogneisses of 2.9-2.65 Ga (Dobrzhinetskaya et al., 1995; Levchenkov et al., 1995). Bordering the Sørvaranger-Kola Terrane to the southwest is the Polmak-Pasvik-Pechenga greenstone belt (PPP) which represents a former rifted ocean basin (Kola Ocean; Lahtinen et al., 2008), interpreted by Berthelsen \& Marker (1986) and Melezhik \& Sturt (1994) as a collisional suture zone. West of the PPP is the Inari Terrane (IT) (Fig. 2) comprising mainly migmatitic orthogneisses, and this in turn is succeeded by the Palaeoproterozoic granulite-facies rocks of the Lapland Granulite Belt (LGB) (Koslov et al., 1995; Daly et al., 2006). The southwestern border of the LGB is a shallowly NE-dipping thrust zone with spectacular blastomylonites, subjacent to which is the highly strained, mélange-like Tanaelv Belt (TB) (Fig. 2).

Directly southwest of the Tanaelv Belt is the Karelian Craton which in central Finnmarksvidda includes two, distinctive, Palaeoproterozoic (2.4-2.0 Ga) greenstone belts and an intervening, Neoarchaean, basement complex (Siedlecka et al., 1985), with another gneiss complex bordering to the southwest. These terranes, the Karasjok Greenstone Belt (KSGB), Jergol Gneiss Complex (JGC), Kautokeino Greenstone Belt (KKGB) and Ráiseatnu Gneiss Complex (RGC) (Fig. 2), are described in detail in other contributions, some of which are in this volume (Braathen \& Davidsen, 2000; Henderson et al., 2015; Melezhik et al., 2015; Bingen et al., 2015).

Rocks of a comparable age to those on Finnmarksvidda occur on islands in western Troms in the horst-like culmination termed the West Troms Basement Complex (WTBC) (Fig. 2; Zwaan, 1995; Bergh et al., 2007, 2010). Several NNW-SSE-trending shear zones and shear belts dissect the WTBC and can be followed inland beneath the Caledonian thrust sheets into the Svecofennian province of northern Sweden and Finland. There is also 

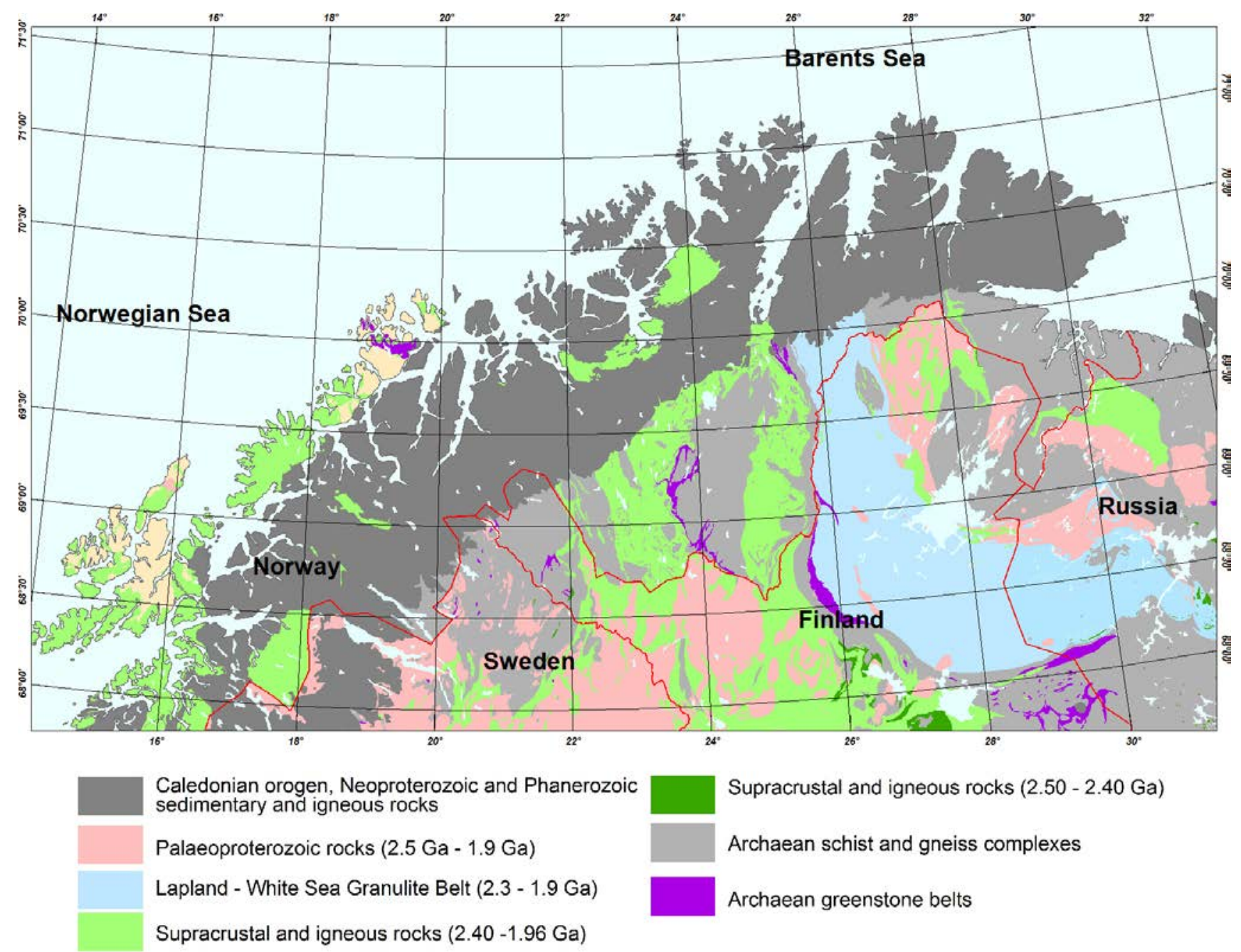

Caledonian orogen, Neoproterozoic and Phanerozoic sedimentary and igneous rocks

Palaeoproterozoic rocks $(2.5 \mathrm{Ga}-1.9 \mathrm{Ga})$

Lapland - White Sea Granulite Belt (2.3 - 1.9 Ga)

Supracrustal and igneous rocks $(2.40-1.96 \mathrm{Ga})$

Supracrustal and igneous rocks $(2.50-2.40 \mathrm{Ga})$

Archaean schist and gneiss complexes

Archaean greenstone belts

Figure 1. Tectonostratigraphic map of northern Scandinavia (modified from Koistinen et al., 2001).

a cover sequence dating to $2.4-2.2 \mathrm{Ga}$ on one of the islands (Bergh et al., 2007). The WTBC is bordered to the southwest - outside the study area - by the anorthositemangerite-charnockite-granite suite of Vesterålen and Lofoten (Griffin et al., 1978).

Taking the Neoarchaean and Palaeoproterozoic terranes of eastern Finnmark and western Troms as a whole, all are characterised by complex, polyphasal, tectonothermal and magmatic histories. With the exception of the Sørvaranger-Kola Terrane, all the other basement complexes and belts were ultimately affected by the composite Svecofennian orogeny (c. 1.92-1.79 $\mathrm{Ga}$ ) (Lahtinen et al., 2008). These orogenic pulses are not directly relevant to this present contribution, but detailed descriptions can be found in many of the publications cited above.

The Caledonide orogen extends the full strike length of our study area from Varanger Peninsula in the northeast to Senja in the southwest, and its continuation offshore to the north across the Finnmark Platform has been documented in recent years with the aid of highresolution aeromagnetic data (Gernigon \& Brönner, 2012; Gernigon et al., 2014). The Caledonides in Scandinavia consist of allochthonous representatives of the Neoproterozoic Baltoscandian margin of Baltica and overlying, more exotic, oceanic and Laurentian terranes (Roberts \& Gee, 1985; Stephens \& Gee, 1989). Platformal deposits now constitute the Lower Allochthon, directly above a thin, autochthonous cover sequence. These are succeeded by the mainly arenaceous rocks of the continental rise, forming the Middle Allochthon. The Upper Allochthon consists of a variety of CambroOrdovician, volcanosedimentary island-arc rocks and fragmented ophiolite assemblages from the Iapetus Ocean (e.g., Slagstad et al., 2014). Finally, the Uppermost Allochthon comprises metasedimentary and magmatic rocks derived from the Laurentian margin of Iapetus or, in part, from intraoceanic ribbon microcontinents and island arcs (Stephens \& Gee, 1989; Roberts et al., 2007).

In Finnmark, the platformal successions are found in the Gaissa Nappe Complex (GNC) (Fig. 2), whilst the 


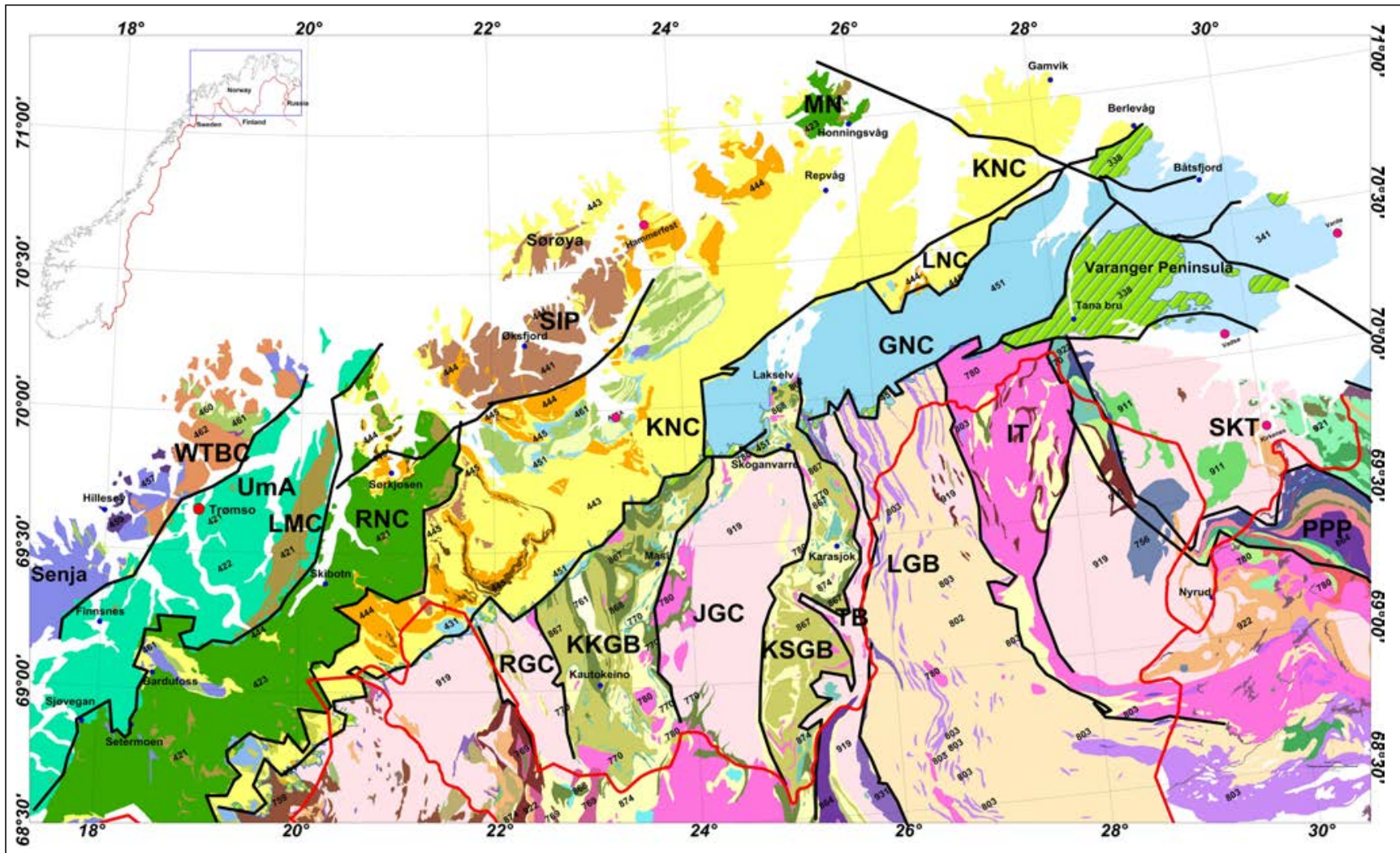

Figure 2. Geological map of the study area. The map is modified and simplified from Koistinen et al. (2001), with colour changes that specifically distinguish the different Archaean-Palaeoproterozoic terranes and the principal tectonostratigraphic elements of the Caledonides as mentioned and discussed in the text. Abbreviations: GNC - Gaissa Nappe Complex, IT - Inari Terrane, JGC - Jergol Gneiss Complex, KKGB Kautokeino Greenstone Belt, KNC - Kalak Nappe Complex, KSGB - Karasjok Greenstone Belt, LGB - Lapland Granulite Belt, LMC - Lyngen Magmatic Complex, LNC - Laksefjord Nappe Complex, MN - Magerøy Nappe, PPP - Polmak-Pasvik-Pechenga, RGC - Ráiseatnu Gneiss Complex, RNC - Reisa Nappe Complex, SIP - Seiland Igneous Province, SKT - Sørvaranger-Kola Terrane, TB - Tanaelv Belt, UmA - Uppermost Allochthon in northern and central Troms, WTBC - West Troms Basement Complex. The solid black lines show the approximate boundaries of the major geological structures. Red lines depict the international borders.

Middle Allochthon is represented by the Laksefjord and Kalak nappe complexes (LNC and KNC, respectively). In western Finnmark the highest nappe of the KNC contains the voluminous Seiland Igneous Province (SIP) of Ediacaran ultramafic, mafic and alkaline rocks (Robins \& Gardner, 1975; Robins, 1982, 1996; Bennett et al., 1986; Robins et al., 1991; Roberts et al., 2006). A higher unit, the Magerøy Nappe (MN), is now considered to show Laurentian affinities (Corfu et al., 2006). The KNC continues to the southwest into Troms county where it is overlain by four separate nappes of the Reisa Nappe Complex (RNC), constituting the Upper Allochthon. Above this we encounter diverse nappes of the Uppermost Allochthon (Fig. 2).

We will return to several of these nappes or nappe complexes in the 'Discussion' section, insofar as we can relate their lithological and mineralogical compositions to particular, prominent anomalies that are depicted quite clearly in the high-resolution aeromagnetic data or in some cases in the radiometric maps.

\section{Geophysical data}

The Mineral Resources in North Norway (MINN) programme, initiated in 2011, was aimed at improving coverage of basic geological information relevant to the assessment of the mineral potential in the three northernmost counties in Norway. This was part of a recent Norwegian governmental strategy for developing the mineral industry in Norway.

Surveying these areas includes taking measurements for magnetism, radioactivity and electrical conductivity, data which are grouped and compared to the existing geochemical and geological data. For geophysical mapping, in the MINN programme fixed-wing aircraft and helicopters were used over Nordland, Troms and Finnmark counties. Along with the geophysical data, NGU continued to expand its geochemical and geological datasets for these counties. In this contribution only the magnetic and radiometric data will be discussed. 


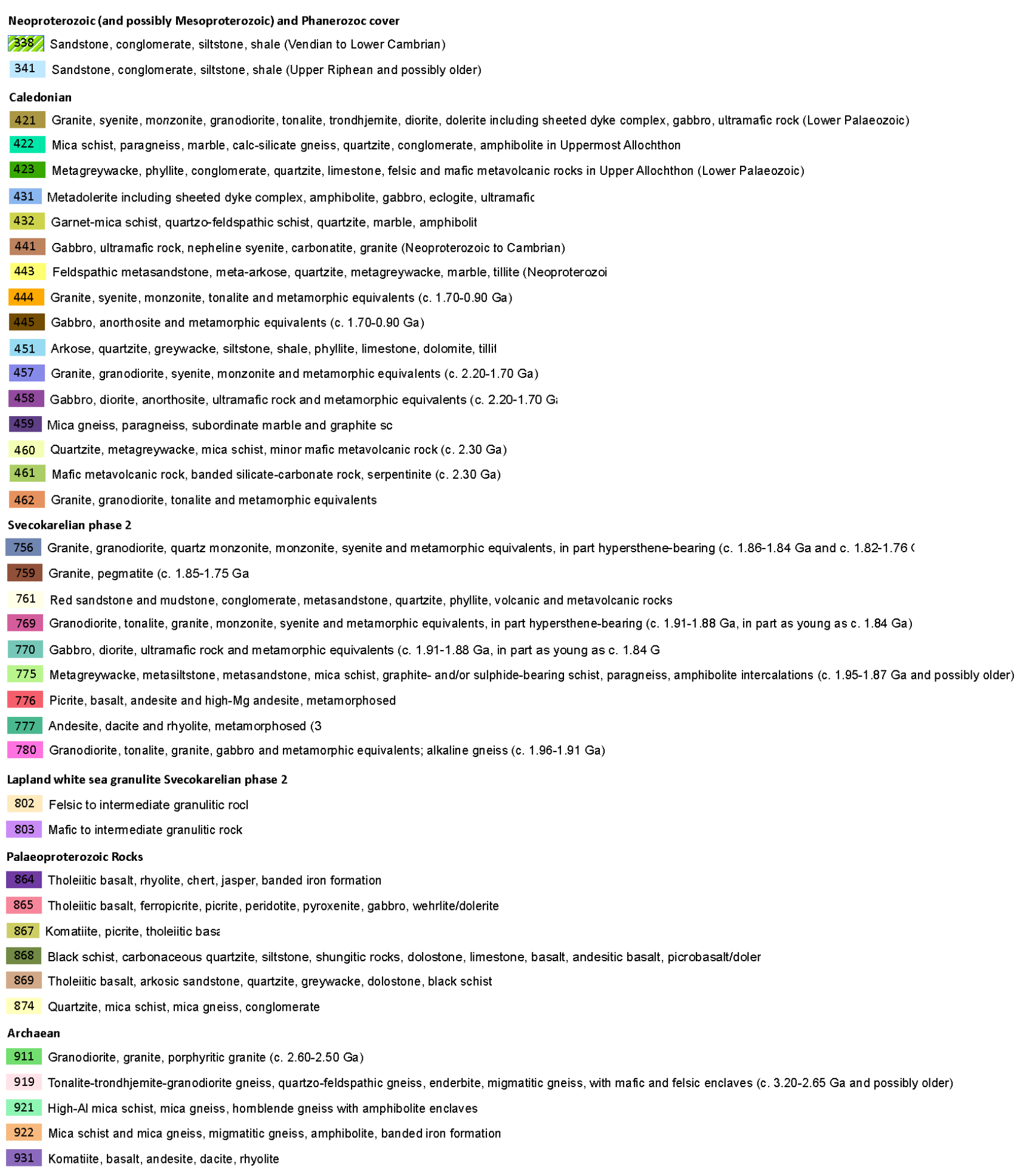

\section{Aeromagnetic data}

Aeromagnetic data can be used to map structures such as faults, folds and dykes, ascertain the thickness of strata in basins and help to locate buried volcanic, as well as some intrusive and metamorphic rocks. Gridded, composite datasets allow us to view continental-scale trends that individual datasets do not provide, and link widely separated areas of outcrop and geological terranes. Individual magnetic surveys must be processed so that they match adjacent surveys prior to merging. Within five years of data acquisition, 2011-2015, for the MINN project, older datasets have been significantly improved and a much larger area than ever before in northern Norway is now covered with high-resolution data. The surface extent of the new geophysical surveys 
covers most of northern Norway, extending from the coastline of the counties of Troms and Finnmark up to the Finnmark Platform at around $71^{\circ}$ north.

In Finnmark, aeromagnetic data in particular have already been applied in investigating the geological structures and greenstone belts (Olesen \& Solli, 1985; Olesen et al., 1990; Olesen \& Sandstad, 1993; Henderson et al., 2015). However, due to inaccurate correction of diurnal artefacts, navigation errors and poor resolution of some of the vintage magnetic data acquired in the 1960s and 1970s in northernmost Norway, the corresponding magnetic dataset (e.g., Skilbrei et al., 1991; Olesen et al., 2010) was of relatively low quality and not entirely reliable for accurate qualitative and quantitative interpretation. It was therefore decided to remap the entire Finnmark region with state-of-the-art, highresolution aeromagnetic data in order to update and replace the vintage magnetic dataset (Fig. 3). The new surveys were carried out during the summers of 2011, 2012 and 2014. These are the new FRAS and TROFI surveys (Novatem, 2012, 2014; EON Geosciences Inc., 2015). Some parts of the study area were also covered by higher resolution heliborne surveys.

The new fixed-wing aeromagnetic surveys (partially extending also into the offshore domain) were carried out in a line/tie-line configuration with profile spacings of $0.2 / 2 \mathrm{~km}$ for FRAS, $0.25 / 2.5 \mathrm{~km}$ for TROFI-14 East, $0.5 / 5$ $\mathrm{km}$ for TROFI-14 Central and 1/10 km (for TROFI-14 West (Table 1). During the acquisition, the sensor altitude adopted a nominal drape flying altitude between 60 and $200 \mathrm{~m}$. The line spacing and flight altitudes are chosen based on geological importance and terrain conditions. The relatively high number of tie-lines was required for the large diurnal variations in such high-latitude areas and were therefore acquired to ensure proper processing and levelling of the data. The raw data have been processed using both statistical and microlevelling methods (using the Oasis Montaj software). 91,210 km of new aeromagnetic profiles were originally acquired by NOVATEM airborne geophysics (Novatem, 2012, 2014) and EON Geosciences (EON Geosciences Inc., 2015) on behalf of the Geological Survey of Norway (NGU).

The heliborne data have been acquired with $200 \mathrm{~m}$ line spacing and with a nominal altitude of $60 \mathrm{~m}$ (Table 2). For these data, tie-lines were not acquired. Instead, stationary magnetic stations were used as reference for diurnal correction.

Besides the newly acquired data, older data from the 1979-91 Kautokeino Surveys have been reprocessed and significantly improved using new software and levelling

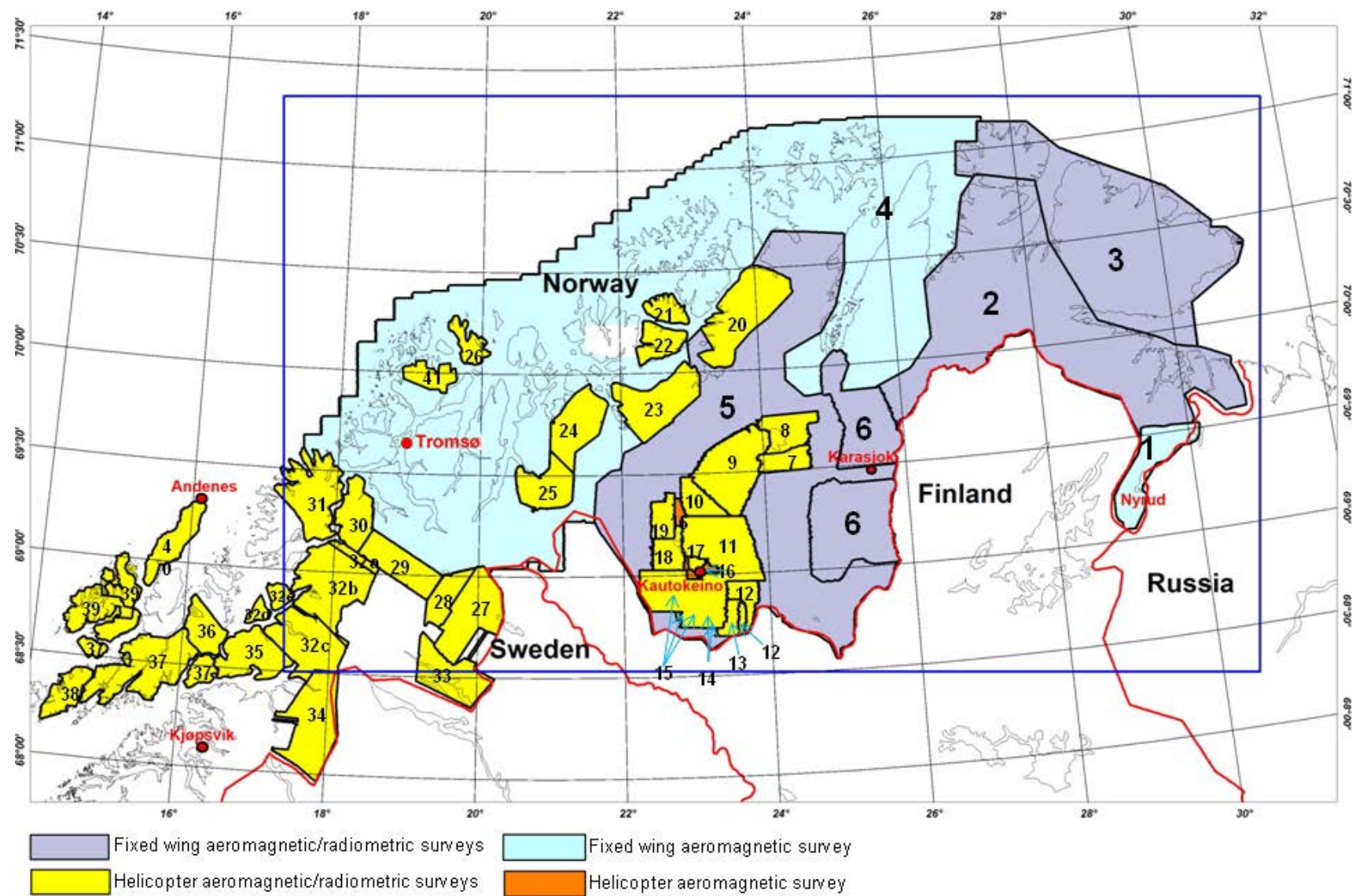

Figure 3. Aeromagnetic and radiometric surveys carried out for the MINN programme. The numbers refer to different surveys (Tables 1 \& 2). The blue box shows the study area for the present contribution. 
Table 1. Fixed-wing surveys. The rows coloured blue indicate that only magnetics were measured in these particular surveys.

\begin{tabular}{|c|c|c|c|c|c|c|c|}
\hline $\begin{array}{c}\text { Number on } \\
\text { the map }\end{array}$ & Year & Area & Survey name & $\begin{array}{c}\text { Sensor elevation } \\
m\end{array}$ & Line spacing $m$ & $\begin{array}{c}\text { Length } \\
\mathrm{km}\end{array}$ & Reference \\
\hline 1 & 1993 & Varanger & $\begin{array}{l}\text { Pasvik South } \\
\text { Pechenga }\end{array}$ & 120 & 120 & 12.541 & $\begin{array}{c}\text { St. Petersburg } \\
\text { Geophysical } \\
\text { Expedition, Russia }\end{array}$ \\
\hline 2 & 2011-2012 & Finnmark & FRAS-11E & 60 & 200 & 58.800 & Novatem Inc. 2012 \\
\hline 3 & 2014 & North Finnmark & TROFI-14 E & 60 & 250 & 38.658 & Novatem Inc. 2014 \\
\hline 4 & 2014 & $\begin{array}{l}\text { Finnmark, } \\
\text { North Troms }\end{array}$ & TROFI-14 W-C & 200 & $500-1000$ & 52.552 & $\begin{array}{l}\text { EON Geoscience } \\
\text { Inc. } 2015\end{array}$ \\
\hline 5 & 2011-2012 & Finnmark & FRAS-11W & 60 & 200 & 82.584 & Novatem Inc. 2012 \\
\hline 6 & 2007-2009 & $\begin{array}{l}\text { Finnmark, } \\
\text { Karasjok }\end{array}$ & GTK-Karasjok & 30 & 200 & 19.496 & $\begin{array}{c}\text { GTK. } \\
\text { Kurimo } 2007,2008 \\
\& 2009\end{array}$ \\
\hline
\end{tabular}

system (Oasis montaj 2015). Furthermore, the highresolution Karasjok aeromagnetic survey operated by and acquired by GTK (Kurimo, 2007, 2008, 2009) has been merged with the new data. In addition to the Norwegian database we have also included part of the aeromagnetic data from the Geological Survey of Sweden (SGU) and the Geological Survey of Finland (GTK) (Airo, 2005; Moore, 2008). This has allowed us to trace the continuation of geological structures across the international borders. The final compiled data are shown in Fig. 4. The differences in the data resolution of the surveys are visible in the composite data. These differences are caused either by variable line spacing or by the altitude of the aircraft for the data acquisitions in each survey. Not surprisingly, lower ground clearance, steeper climb/descent rate and tighter line spacing provide better and higher resolution data. We have not applied a direct upward or downward continuation of the dataset because the main purpose has been to show the actual resolution of the data.

A number of filtering and image enhancements have been subsequently calculated from the magnetic total field to enhance specific magnetic trends and anomalies. Filtering and derivative calculations, especially the normalised tilt-derivative filtering (TDR) (Miller \& Singh, 1994; Verduzco et al., 2004), helped to define different basement domains, subvertical geological boundaries, faults and dykes (Fig. 4B). The TDR filter increased the amplitude of the magnetic total field anomalies and provided an effective alternative to the vertical derivative to map the continuity of the dykes that crop out only very locally in the region.

\section{Radiometry data}

Radioactivity is the process of decay or disintegration of an unstable atomic nucleus usually accompanied by the emission of radiation (Heinrich, 1958). Radioactivity in minerals is caused by the presence of naturally occurring radioactive elements and depends on the concentration and isotope present in the mineral. Many hundreds of naturally occurring radioactive isotopes exist. Only three are commonly measured and used in geophysical mapping and mineral exploration (Faure, 1977). These are potassium $\left({ }^{40} \mathrm{~K}\right)$, uranium $\left({ }^{238} \mathrm{U}\right)$ and thorium $\left({ }^{232} \mathrm{Th}\right)$. These radioelements can be detected by airborne gamma ray spectrometry as they emit a sufficient intensity of gamma radiation.

Airborne measurements of the intensity of the main radioactive isotopes ( $\mathrm{K}, \mathrm{U}$ and $\mathrm{Th}$ ) directly reflects the geochemical variations of these elements present in soil and rocks within the upper $30-50 \mathrm{~cm}$ of the Earth's crust. Potassium is a major component comprising $2.35 \%$ of the Earth's crust and is commonly found in $\mathrm{K}$-feldspars and micas. Uranium and thorium are minor components comprising $\sim 3$ and $\sim 12 \mathrm{ppm}$ of the Earth's crust, respectively. Uranium occurs in rocks as U-oxide, U-silicate, uraninite, uranothorite. monazite, xenotime and zircon. Thorium occurs in allanite, monazite, xenotime and zircon. In general, the radioelement concentrations increase with an increasing Si content.

Since 2011, NGU has acquired numerous airborne spectrometry datasets along with the aeromagnetic data with fixed-wing and rotary wing aircraft at a nominal flight clearance of $60 \mathrm{~m}$ (see Table 2 \& Fig. 3). With the acquisition of these high-resolution surveys arose the need to reprocess the data acquired between 1979 and 1991 to achieve a homogeneous compilation. The several instruments of variable accuracy and sensitivity used throughout the years explain the variation in the data quality. In some cases, half the detector volume was used to acquire spectrometric data. Also, processing methods, navigation technology and other geophysical instruments have improved in recent decades. Details of the instrument specifications, reprocessing and compiling procedures are documented in Dumais (2014). Reprocessing was performed using standard levelling and microlevelling. These methods were chosen since no spectral data were available to allow a full recalibration and reprocessing of the data. An example of one of the results of reprocessing is shown in Fig. 5. 
Table 2. Helicopter surveys. The row coloured orange indicates that only magnetics were measured in this particular survey.

\begin{tabular}{|c|c|c|c|c|c|c|c|}
\hline $\begin{array}{c}\text { Number on } \\
\text { the map }\end{array}$ & Year & Area & Survey name & $\begin{array}{c}\text { Sensor elevation } \\
m \\
\end{array}$ & $\begin{array}{c}\text { Line spacing } \\
m\end{array}$ & $\begin{array}{c}\text { Length } \\
\mathrm{km}\end{array}$ & Reference \\
\hline 7 & 1985 & Finnmark & Karasjok & 60 & 250 & 4.200 & Håbrekke, 1985 \\
\hline 8 & 1983 & Finnmark & Lesjavri & 60 & 200 & 3.250 & Håbrekke, 1984 \\
\hline 9 & 1982 & Finnmark & Suoluopmi. Caravari & 60 & 250 & 5.250 & Håbrekke, 1983a, b \\
\hline 10 & 1983 & Finnmark & Caravari & 60 & 200 & 3.250 & Håbrekke, 1984 \\
\hline 11 & 1985 & Finnmark & Kautokeino & 60 & 200 & 8.000 & $\begin{array}{c}\text { Mogaard \& Skilbrei, } \\
1986\end{array}$ \\
\hline 12 & 1980 & Finnmark & Lavvoaivi, Siebe 1980 & & & & Håbrekke, 1980a \\
\hline 13 & 1979 & Finnmark & Lavvoaivi, Siebe 1979 & 60 & 200 & 1000 & Håbrekke, 1979 \\
\hline 14 & 1991 & Finnmark & $\begin{array}{c}\text { Siebe, Roavvoaivi } \\
1991\end{array}$ & 60 & 50 & 801 & Walker, 1991 \\
\hline 15 & 1989 & Finnmark & Siebe & 60 & $50-100$ & 2.017 & Håbrekke et al., 1990 \\
\hline 16 & 1982 & Finnmark & Kautokeino & & 200 & 2.047 & Dvorak, 1982 \\
\hline 17 & 1991 & Finnmark & Kautokeino & 60 & 50 & 1.649 & Walker, 1991 \\
\hline 18 & 1981 & Finnmark & Raisjavri & 60 & 200 & 1.900 & Håbrekke, 1981 \\
\hline 19 & 1980 & Finnmark & Bidjovagge & 60 & 200 & 1500 & Håbrekke, 1980b \\
\hline 20 & 2011 & Finnmark & Alta, Kvalsund & 58 & 200 & 6.000 & Ofstad et al., 2013 \\
\hline 21 & $213-2014$ & Finnmark & Alta, Hasvik, Loppa & 65 & 200 & 1.347 & Rodionov et al., 2014a \\
\hline 22 & 2013 & Finnmark & Øksfjord & 75 & 200 & 2.084 & Rodionov et al., 2013d \\
\hline 23 & 2012 & $\begin{array}{l}\text { Troms and } \\
\text { Finnmark }\end{array}$ & Alta-Kvænangen & 58 & 200 & 5.526 & Rodionov et al., 2012e \\
\hline 24 & 2015 & Troms & Nordsreisa & 56 & 200 & 4.286 & Rodionov et al., 2015 \\
\hline 25 & 2014 & Troms & $\begin{array}{l}\text { Kåfjord and } \\
\text { Nordreisa }\end{array}$ & 59 & 200 & 3.106 & Rodionov et al., 2014c \\
\hline 26 & 2011 & Troms & Vanna & 59 & 200 & 1.336 & $\begin{array}{l}\text { Rodionov \& Ofstad, } \\
2012 \mathrm{a}\end{array}$ \\
\hline 27 & 2015 & Troms & Øvre Dividalen & 50 & 200 & 5.500 & Ofstad, 2015b \\
\hline 28 & 2013-2014 & Troms & Dividalen & 75 & 200 & 2.014 & Ofstad, 2015a \\
\hline 29 & 2011 & Troms & Mauken & 45 & 200 & 3.680 & Rodionov et al., 2012a \\
\hline 30 & 2012 & Troms & Finnses & 55 & 200 & 2715 & Rodionov et al., 2012d \\
\hline 31 & $2012-2014$ & Troms & Senja & 60 & 100 and 200 & 5.620 & Rodionov et al., 2014b \\
\hline $32 \mathrm{a}$ & 2012 & \multirow{5}{*}{ Troms } & \multirow{5}{*}{$\begin{array}{l}\text { Narvik, Skånland, } \\
\text { Ibestad, Gratangen, } \\
\text { Lavangen, Salangen, } \\
\text { Dyrøy, Sørreisa and } \\
\text { Bardu }\end{array}$} & \multirow{5}{*}{53} & \multirow{5}{*}{200} & 627 & \multirow{4}{*}{$\begin{array}{l}\text { Stampolidis et al., } \\
2015\end{array}$} \\
\hline $32 b$ & 2014 & & & & & 6664 & \\
\hline $\begin{array}{l}32 \mathrm{c} \\
32 \mathrm{~d}\end{array}$ & $\begin{array}{l}2014 \\
2014\end{array}$ & & & & & $\begin{array}{l}5149 \\
574\end{array}$ & \\
\hline $32 \mathrm{e}$ & 2014 & & & & & 787 & \\
\hline \multicolumn{4}{|l|}{574} & & & & \\
\hline 33 & 2013 & $\begin{array}{l}\text { Nordland and } \\
\text { Troms }\end{array}$ & Altevann & 70 & 200 & 4.160 & $\begin{array}{l}\text { Ofstad \& Stampolidis, } \\
\qquad 2014\end{array}$ \\
\hline 34 & 2011 & Nordland & Rombaken & 64 & 200 & 5.218 & $\begin{array}{l}\text { Rodionov \& Ofstad, } \\
\text { 2012b }\end{array}$ \\
\hline 35 & 2013 & $\begin{array}{l}\text { Nordland and } \\
\text { Troms }\end{array}$ & Evenes & 54 & 200 & 3.934 & Rodionov et al., $2013 \mathrm{c}$ \\
\hline 36 & 2012 & Troms & Kvæfjord & 51 & 200 & 2.190 & Rodionov et al., 2012b \\
\hline 37 & 2013 & $\begin{array}{l}\text { Nordland and } \\
\text { Troms }\end{array}$ & $\begin{array}{c}\text { Austvågøya, } \\
\text { Hinnøya, Tjeldøya } \\
\text { and Hadseløya }\end{array}$ & 75 & 200 & 8.100 & Stampolidis et al., 2014 \\
\hline 38 & 2013 & Nordland & Austvågøya & 53 & 200 & 1.956 & Rodionov et al., 2013a \\
\hline 39 & 2013 & Nordland & Langøya & 55 & 200 & 5.650 & Rodionov et al., 2013b \\
\hline 40 & 2012 & Nordland & Andøya & 56 & 200 & 2.614 & Rodionov et al., 2012c \\
\hline 41 & 2001 & Troms & Ringvassøy & 60 & 200 & 1.589 & $\begin{array}{l}\text { Mogaard \& Mauring, } \\
2002\end{array}$ \\
\hline
\end{tabular}



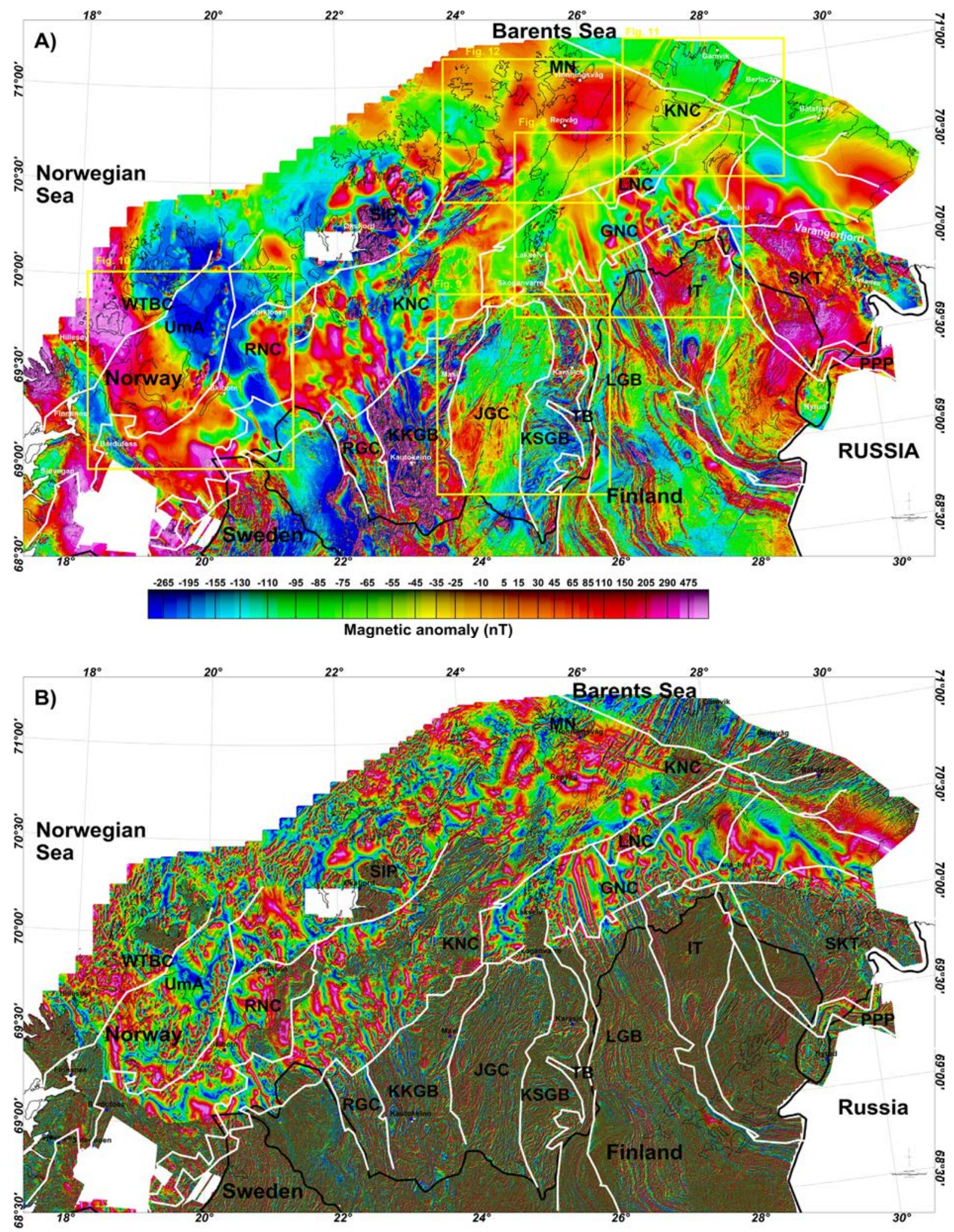

$\begin{array}{lllllllllllllllllllllll}-1.43 & -1.30 & -1.20 & -1.10 & -1.00 & -0.90 & -0.79 & -0.67 & -0.55 & -0.42 & -0.27 & -0.11 & 0.05 & 0.21 & 0.39 & 0.57 & 0.75 & 0.94 & 1.16\end{array}$

Tilt derivative (radian)

Figure 4. Aeromagnetic data of the study area (see Fig. 3). (A) Aeromagnetic anomaly map. (B) Tilt-derivative map of the magnetic data. Abbreviations: GNC - Gaissa Nappe Complex, IT - Inari Terrane, JGC - Jergol Gneiss Complex, KKGB - Kautokeino Greenstone Belt, KNC Kalak Nappe Complex, KSGB - Karasjok Greenstone Belt, LGB - Lapland Granulite Belt, LNC - Laksefjord Nappe Complex, MN - Magerøy Nappe, PPP - Polmak-Pasvik-Pechenga, RGC - Ráiseatnu Gneiss Complex, RNC - Reisa Nappe Complex, SIP - Seiland Igneous Province, SKT - Sørvaranger-Kola Terrane, TB - Tanaelv Belt, UmA - Uppermost Allochthon in northern and central Troms, WTBC - West Troms Basement Complex. The solid white lines show the approximate boundaries of the major geological terranes. The outlines of Figs. 8, 9, 10, 11 \& 12 are shown by the yellow boxes. 

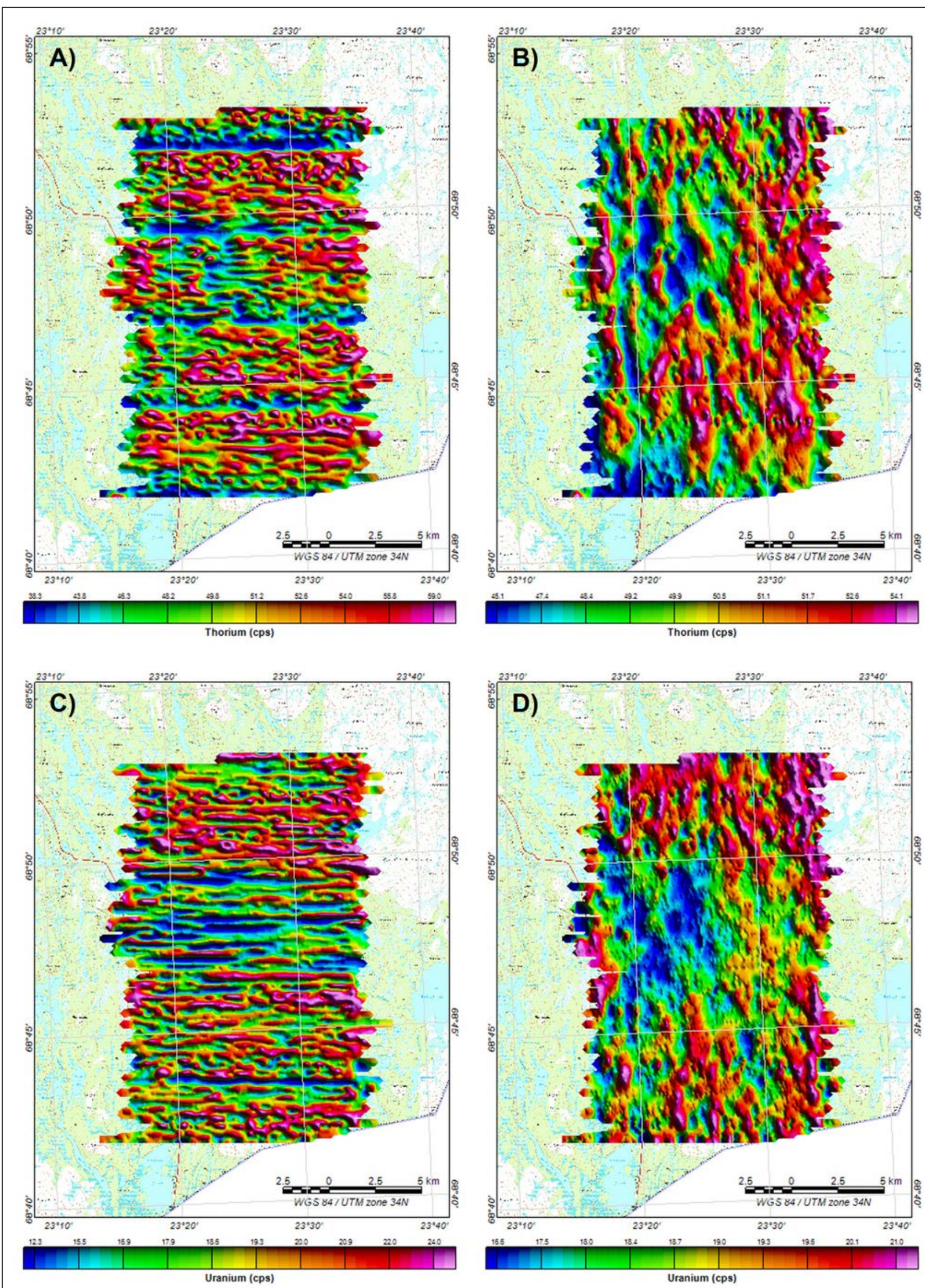

Figure 5. Reprocessing of radiometric data from Siebe, Lavvoaivi - 1979 (survey no. 13 in Table 2 \& Fig. 3). (A, B) Thorium before and after reprocessing. (C, D) Uranium before and after reprocessing. 
Sensitivity calibration is not available for data acquired prior to 1991. No equivalent concentration can be derived directly from the measurements. To obtain the concentrations from these datasets, a concentration reference must be used. The surveys acquired since 2011 were designed to overlap the older uncalibrated data. Hence, they were used as a reference to calculate the concentrations.

The final compilation shows small variations between the survey datasets (Fig. 6). This is particularly visible for uranium (Fig. 6C), where shifts between datasets are in the order of a tenth of ppm. This error is largely due to the regression calculation and the low counts detected (caused by the low uranium content of the area and crystal volume used). For comparison, today's instruments may provide an accuracy of $0.01 \mathrm{ppm}$.

The image used to represent radiometric data can also be presented as a so-called ternary image of the relative concentrations of the three major elements and is generated from the gridded concentrations of each element. The red-coloured areas are generally rich in potassium, while the blue and green areas are indicating high contents of uranium and thorium, respectively. White zones are indicative of high concentrations of all elements. In contrast, darker zones suggest the presence of magnetite-rich ultramafic rocks with very low concentrations of all three elements. The ternary image of the study area is shown in Fig. 7.

\section{Results and discussion}

In this chapter we discuss the results of the aeromagnetic and radiometric surveys, starting with the oldest terranes in the extreme northeast and progressing southwestwards across Finnmarksvidda, then passing across to the comparable basement terranes of western Troms before dealing with the nappe complexes of the Caledonides. In doing so we will highlight some of the principal magnetic anomalies, folded anomalies and anomaly offsets, as well as radiometric zoning patterns, and relate such features to the bedrock geology of this vast region.

The Neoarchaean Sørvaranger-Kola Terrane (SKT) (Fig. 2) in northeastern Finnmark borders the Murmansk Craton across the deep-seated, dextral strike-slip, Murmansk Shear Zone (Karpuz et al., 1995). The terrane is covered by two different aeromagnetic/radiometric databases, the newly acquired FRAS-11E in the north and older data from 1993 in the southern part (Surveys 1 \& 2 in Fig. 2). Both databases provide detailed magnetic information but only FRAS-11E includes radiometric measurements (Fig. $3 \&$ Table 1). Lineaments such as major faults, shear zones and even thick dykes can be detected quite clearly using these data, especially where aeromagnetic anomalies show offsets or are abruptly truncated (see also Henderson et al., 2015; Nasuti et al., 2015). The orientations of these lineaments vary across the SKT but are mostly NW-SE to NNW-SSE. Structural details of many of the major shear zones have been reported in Karpuz et al. (1995) and Roberts et al. (1997). In addition to the lineaments there are several distinctive magnetic anomalies in the region. As an example, the commercially exploited banded iron formation of the Bjørnevann Group (Siedlecka et al., 1985), which shows high magnetic amplitudes, can be traced over $100 \mathrm{~km}$ northwestwards from Kirkenes to the Varangerfjord (Fig. 4A; Bugge, 1978). On the ternary map of radiometric data, the SKT is shown with very pale green colours indicating high levels of $\mathrm{K}, \mathrm{U}$ and a predominance of Th (Fig. 7). This is clearly associated with the widespread presence of the Neoarchaean high- $\mathrm{K}$ granites and granodiorites in this terrane. The reddish-brown colours, on the other hand, are indicative of $\mathrm{K}$ and Th enrichment in some of the mafic igneous rocks.

To the north of Nyrud, a prominent linear magnetic feature on the magnetic and TDR maps (Fig. 4A, B) corresponds to the boundary between the SKT and the Polmak-Pasvik-Pechenga greenstone belt (PPP). This greenstone belt, located mainly in Russia, comprises MORB-type tholeiitic basalts and intercalated $\mathrm{Cu}-\mathrm{Ni}$ deposits of Palaeoproterozoic age. The boundary of this now telescoped, oceanic terrane trends $\mathrm{E}-\mathrm{W}$ close to the Norwegian-Russian border, swinging clockwise into a NNW-SSE orientation farther north. Several subparallel magnetic lineaments can be detected along this major boundary. It should be noted that on the magnetic maps the prolongation of the PPP is not clearly delineated in Finnish territory.

The next, major, tectonically delimited belt is the Inari Terrane (IT) (Fig. 2) with its magmatic arctype granodiorites, diorites and gabbros that have yielded Neoarchaean zircon ages in the east/northeast and Palaeoproterozoic ages in the west/southwest (Meriläinen, 1976; Lehtinen et al., 2005; Daly et al., 2006). Subordinate metasupracrustal rocks have also been reported in this terrane. The IT is mostly located in Finland and is covered by high-resolution aeromagnetic data. Where the terrane disappears beneath the low-grade metasedimentary rocks of the lowermost Caledonian Gaissa Nappe Complex (GNC), its lithologies and geological structures can still be followed quite clearly north-northwestwards on the aeromagnetic data. Because of the low-magnetic character of the comparatively thin GNC rocks, the magnetic anomalies are wider and smoother than in areas where the Inari Terrane is fully exposed. It should be noted that the resolution of the Finnish aeromagnetic data is higher than in its Norwegian counterpart, because of the lower flight altitudes $(40 \mathrm{~m})$ of the Finnish survey 


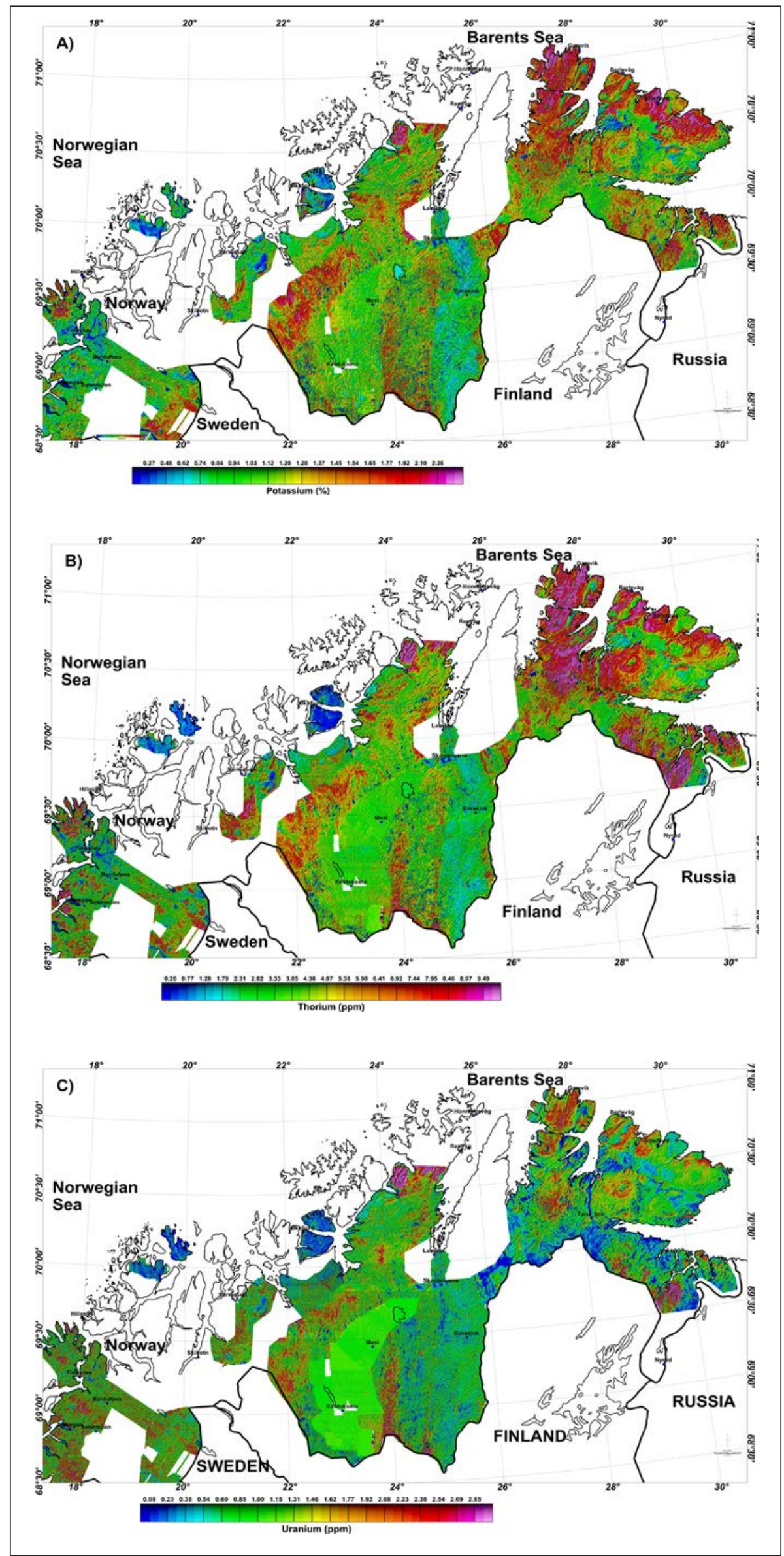

Figure 6. Radiometric data for the study area. (A) Potassium concentrations. (B) Thorium concentrations. (C) Uranium concentrations. See also Fig. 3 \& Table 2 for the details of surveys. 


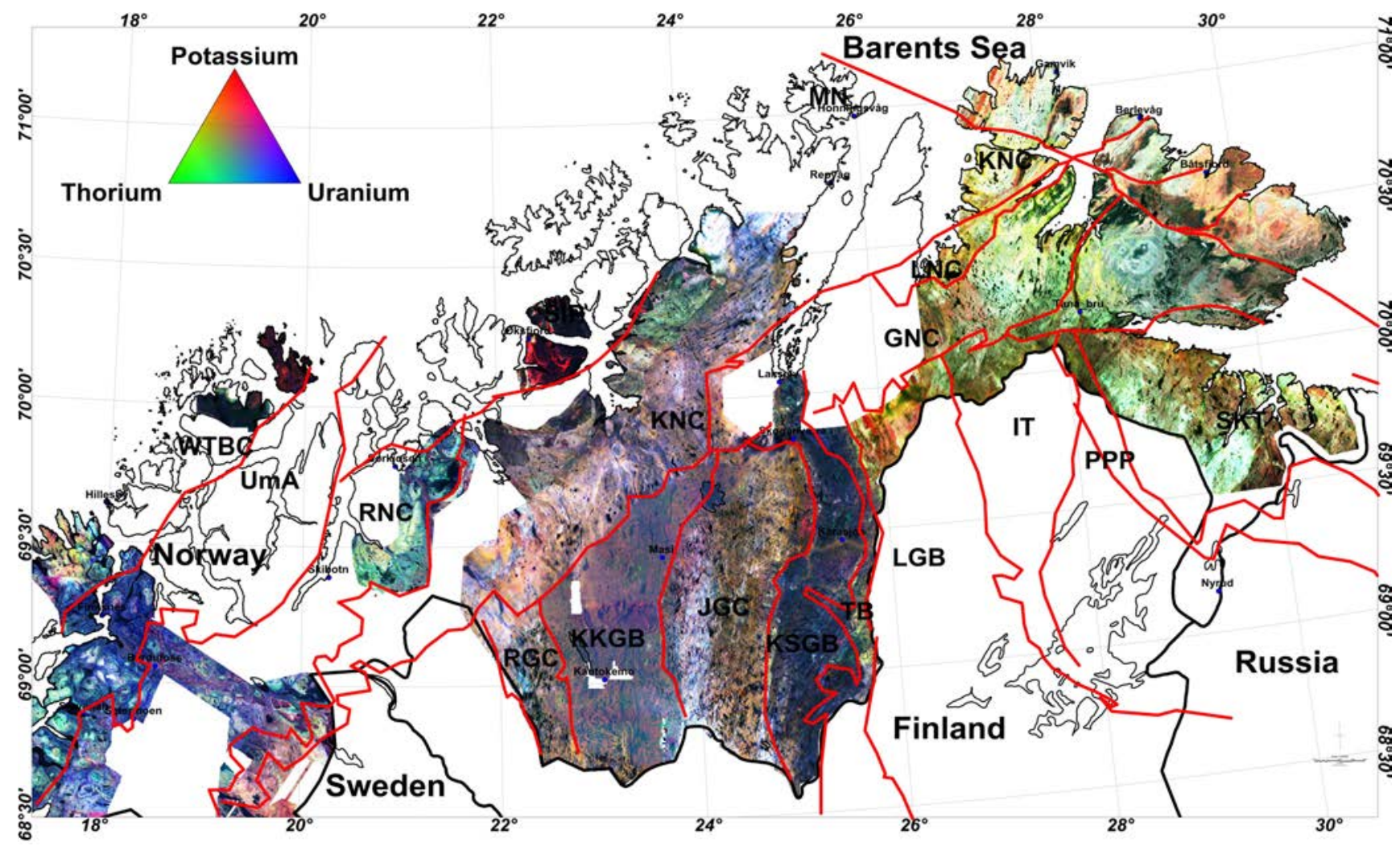

Figure 7. Ternary map of radiometric data. Abbreviations: GNC - Gaissa Nappe Complex, IT - Inari Terrane, JGC - Jergol Gneiss Complex, KKGB - Kautokeino Greenstone Belt, KNC - Kalak Nappe Complex, KSGB - Karasjok Greenstone Belt, LGB - Lapland Granulite Belt, LNC Laksefjord Nappe Complex, MN - Magerøy Nappe, PPP - Polmak-Pasvik-Pechenga, RGC - Ráiseatnu Gneiss Complex, RNC - Reisa Nappe Complex, SIP - Seiland Igneous Province, SKT - Sørvaranger-Kola Terrane, TB - Tanaelv Belt, UmA - Uppermost Allochthon in northern and central Troms, WTBC - West Troms Basement Complex. The solid red lines show the approximate boundaries of the major geological terranes.

(FRAS-11E survey in Figs. 4B \& 8A). In general, there is good correlation between the radiometric data and the geological map. In a few small areas, however, especially in the eastern part of the terrane, the mapped geological boundaries do not correspond with the coloration ascribed to specific radiometric zones (Fig. 8B).

Juxtaposed against the Inari Terrane to the southwest is the Lapland Granulite Belt (LGB) (Fig. 2) which comprises Palaeoproterozoic, granulite-facies, metamorphic and migmatitic rocks such as norite-enderbites, gabbro-anorthosite massifs, high-grade amphibolites and felsic paragneisses (Koslov et al., 1995; Daly et al., 2006). Most of the mafic granulites are high-density rocks, also with high susceptibility, which lead to positive and linear anomaly signatures on aeromagnetic maps (Figs. 4B \& 8A). Similar to the IT terrane, the continuation of the LGB magnetic anomalies can also be followed beneath the Caledonian nappes (mainly GNC) up to Porsangefjorden. Large parts of the LGB are located in Finland where aeromagnetic data show more lineaments but this is mainly due to the higher-resolution datasets (Finnish and FRAS-11E in Fig. 8A). On the ternary map (Fig. $8 \mathrm{~B}$ ), which covers only a small part of the LGB, red linear features are associated with mafic granulites with low Th and $\mathrm{U}$ concentrations but high potassium contents. The green areas are indicative of high Th values whilst yellow points to high concentrations of both $U$ and Th which are associated with felsic rocks. Boundaries of the granulites are very well defined by the aeromagnetic and to a lesser extent by the radiometric data (Fig. 8B). It seems clear that some of the bedrock contacts on the geological map (500,000 map sheet) can be modified based on these data.

The southwestern border of the LGB is a shallowly NE-dipping thrust zone with spectacular blastomylonites, subjacent to which is the Tanaelv Belt (TB) (Fig. 2). This narrow belt is essentially a highly strained, ductile shear zone, akin to a mélange, consisting of migmatised amphibolite-facies basic gneisses containing numerous lenses and fragments of gabbroic, anorthositic and ultramafic rocks (Barbey et al., 1980; Marker, 1985). On the aeromagnetic data, lineaments in the TB are clearly discernible. These lineaments are changing their orientation from NE-SW in the south to mostly NW-SE in the northern part of the belt (Fig. 9A). It is noteworthy that the radioelement content in the TB is also changing from high values in the south to lower radioactive concentrations in the north (Fig. 9B). 


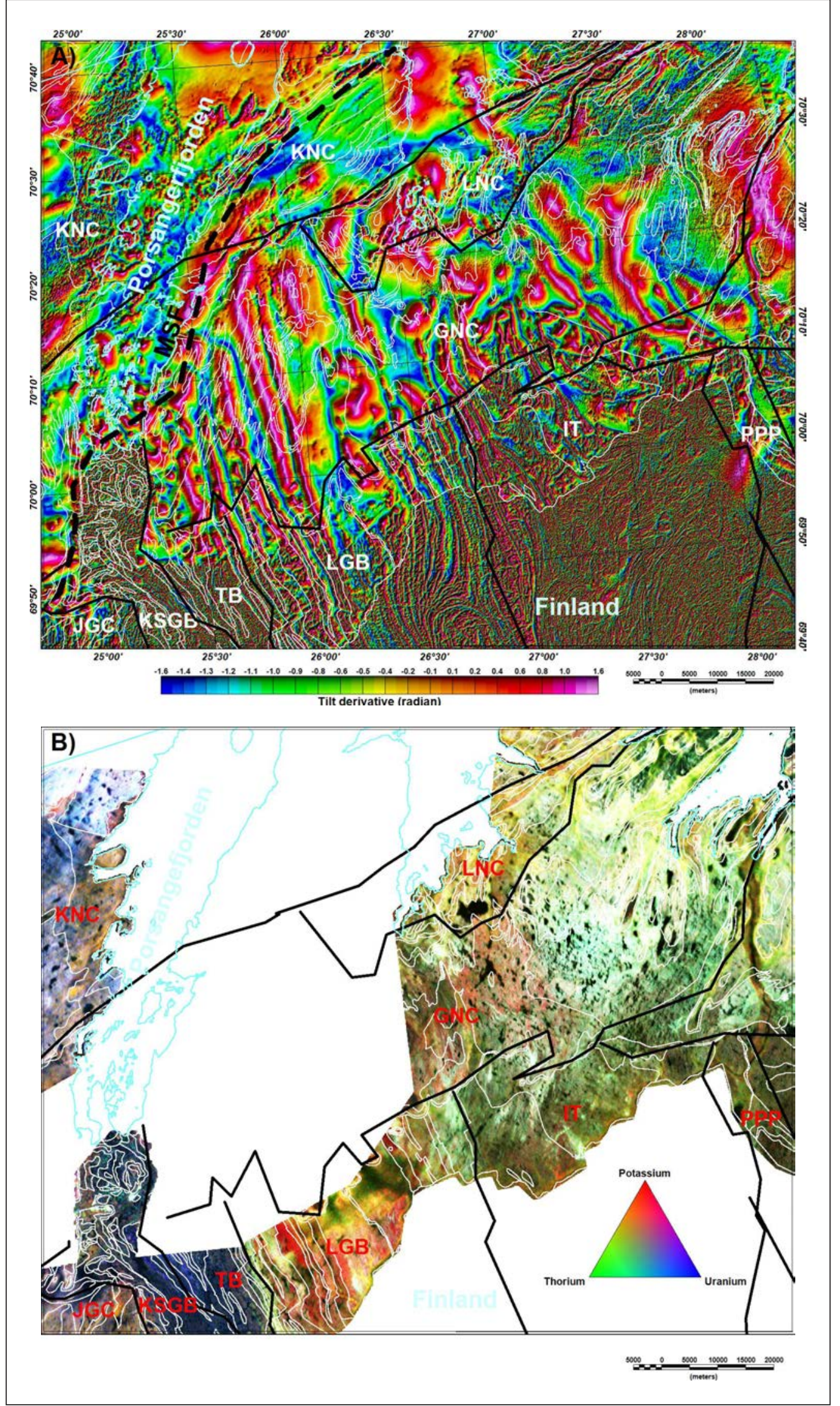

Figure 8. (A) Tilt-derivative of magnetic data. (B) Ternary map of radiometric data. The solid white lines show the geological boundaries based on the 1:500,000 map of Finnmark. The solid black lines show the approximate boundaries of the major geological terranes. Abbreviations: GNC - Gaissa Nappe Complex, IT - Inari Terrane, JGC - Jergol Gneiss Complex, KNC - Kalak Nappe Complex, KSGB - Karasjok Greenstone Belt, LGB - Lapland Granulite Belt, LNC - Laksefjord Nappe Complex, MSF - Mierujavri-Svoerholt fault zone, PPP - PolmakPasvik-Pechenga, TB - Tanaelv Belt. 
Cross-cutting faults and also dykes are visible in the aeromagnetic data within the TB. Some of these structures are not only cutting the TB but also pass into the LGB and extend for several tens of kilometres. Ductile shear zones can be seen where the magnetic lineaments are suddenly bent and slightly displaced. Some of these shear zones are also cross-cut by the later faults. To the northeast and southeast of Karasjok, several semicircular magnetic patterns are recognisable, some of which reflect younger fold structures (Fig. 9A). Other, more curvilinear magnetic anomalies, however, are a consequence of the east-dipping strata having been incised by streams and rivers. Similar to the LGB, it is clear that the TB can be traced under the Caledonian nappes to Porsangefjorden where the NW-SE anomaly trend appears to terminate against the NE-SW-trending Mierujavri-Sværholt fault zone (Fig. 8A; Olesen et al., 1990) The southwestern contact of the TB marks our entry into the domain of the Karelian Craton, represented first by the Karasjok Greenstone Belt.

The Karelian Craton in this part of Finnmark (central Finnmarksvidda) includes two, distinctive, Palaeoproterozoic (2.4-2.0 Ga) greenstone belts and an older, Neoarchaean, gneissic basement complex (Fig. 2; Siedlecka et al., 1985; Bingen et al., 2015). The Karasjok Greenstone Belt (KSGB), below the TB and east of the mainly tonalitic gneisses of the domal Jergol Gneiss Complex (JGC), consists of a thick volcanosedimentary succession divided into several formations with a total thickness in the range 7-10 km (Siedlecka et al., 1985; Midtun, 1988; Skaar, 2014). The lowest formation has been assumed to lie unconformably upon the JGC. The dominant volcanic component includes pillowed tholeiitic basalts (now mostly amphibolites), metakomatiites and banded iron formations (Braathen \& Davidsen, 2000; Melezhik et al., 2015), all of which register with positive anomaly signatures on the aeromagnetic maps (Figs. 4 \& 9A).

The high-resolution aeromagnetic data from the KSGB region (Fig. 9A) reveal a large amount of details concerning the geological structures. Based on the recent research by Skaar (2014), the geological map is in need of revision as it does not match the newly acquired data in some areas. By using 3D geophysical modelling he suggested that the volcanic belt constitutes a significantly smaller part of the KSGB. Furthermore, there is a distinct difference between lineaments occurring to the north of Karasjok and those in the south. Magnetic features strike mostly E-W in the south whereas they are oriented NNW-SSW in the northern part of the belt. The mafic to ultramafic intrusions which are prominent in the central parts appear as structurally complex features, where their geometries have been controlled by NNW-SSE and NESW-striking thrusts and faults. Also, several mafic dykes can be detected in the KSGB region with relatively low susceptibility but very high remanence (Skaar, 2014). As an example, a very prominent, low-magnetic, NE-SW linear anomaly can be seen in the southern part of the belt (Fig. 9A). This strong, negative magnetic anomaly is caused by reversed remanent magnetisation of one particular dyke (Midtun, 1988). It is noteworthy that this particular dyke transects both the supracrustal rocks within the KSGB and the rocks of the TB terrane (Fig. 9A).

The ternary map of the KSGB shows dark magenta to dark purple colours which indicate low contents of $\mathrm{K}, \mathrm{U}$ and even lower of Th in the mafic and ultramafic rocks. Other rocks such as quartz-feldspathic gneisses show high $\mathrm{K}$ contents which can be recognised by their pink to reddish colours on the ternary map (Fig. 9B). The bright green areas are mostly corresponding with high Th contents of quartzite or arkosic rocks, for example in the area north of Karasjok. Based on the new aeromagnetic and radiometric data there is a need for revising current bedrock maps of this poorly exposed region. The sedimentary rocks between the JGC and the KSGB range from polymict conglomerates and fuchsite-bearing quartzites to graphitic schists, quartz-feldspathic gneisses and amphibole-rich schists, with thin intercalations of dolostone. In general, these rocks have lower magnetic values with fewer internal linear features and can also be recognised on the ternary map by their distinct bright colours indicative of a high radioelement content.

The Jergol Gneiss Complex (JGC) can easily be distinguished from the KSGB with its almost uniform brownish colour on the ternary map (Fig. 9B). This relates to the high potassium content of the granitic to tonalitic gneissic rocks, which have been dated (U$\mathrm{Pb}$, zircon) to between c. 2975 and $2775 \mathrm{Ma}$ (Bingen et al., 2015). The radiometric data also show that in the western part of the complex there are bright (whitish) colours indicative of high contents of Th, $\mathrm{U}$ and $\mathrm{K}$ in the bedrock. This is partly where granitic and pegmatite rocks are exposed; and on the magnetic anomaly map this is shown as positive magnetic anomalies. This zone with combined whitish colours and distinctive magnetic signature is more extensive than the small area of the granitic rocks indicated on the geological maps, and signifies that the granite of the Hetta complex (Heilimo et al., 2009) in nearby Finland extends some $60 \mathrm{~km}$ farther north beneath the thin cover of the glacial deposits.

The Kautokeino Greenstone Belt (KKGB) lies to the west of the Jergol gneissic dome and is bordered on its western side by the Ráiseatnu Gneiss Complex (RGC) (Figs. 2 \& 4 ), for a long time considered to be correlative with the Jergol. The eastern and western borders of the belt are intruded by younger granites, granodiorites and diorites. This c. $50 \mathrm{~km}$-wide, strongly sheared, greenstone belt (Olesen et al., 1990; Olesen \& Sandstad, 1993; Henderson et al., 2015; Bingen et al., 2015) is dominated by mafic volcanic rocks but also includes two metasedimentary formations. Amphibolitised basaltic volcanites are the principal lithologies, both lavas and tuffs, also with 


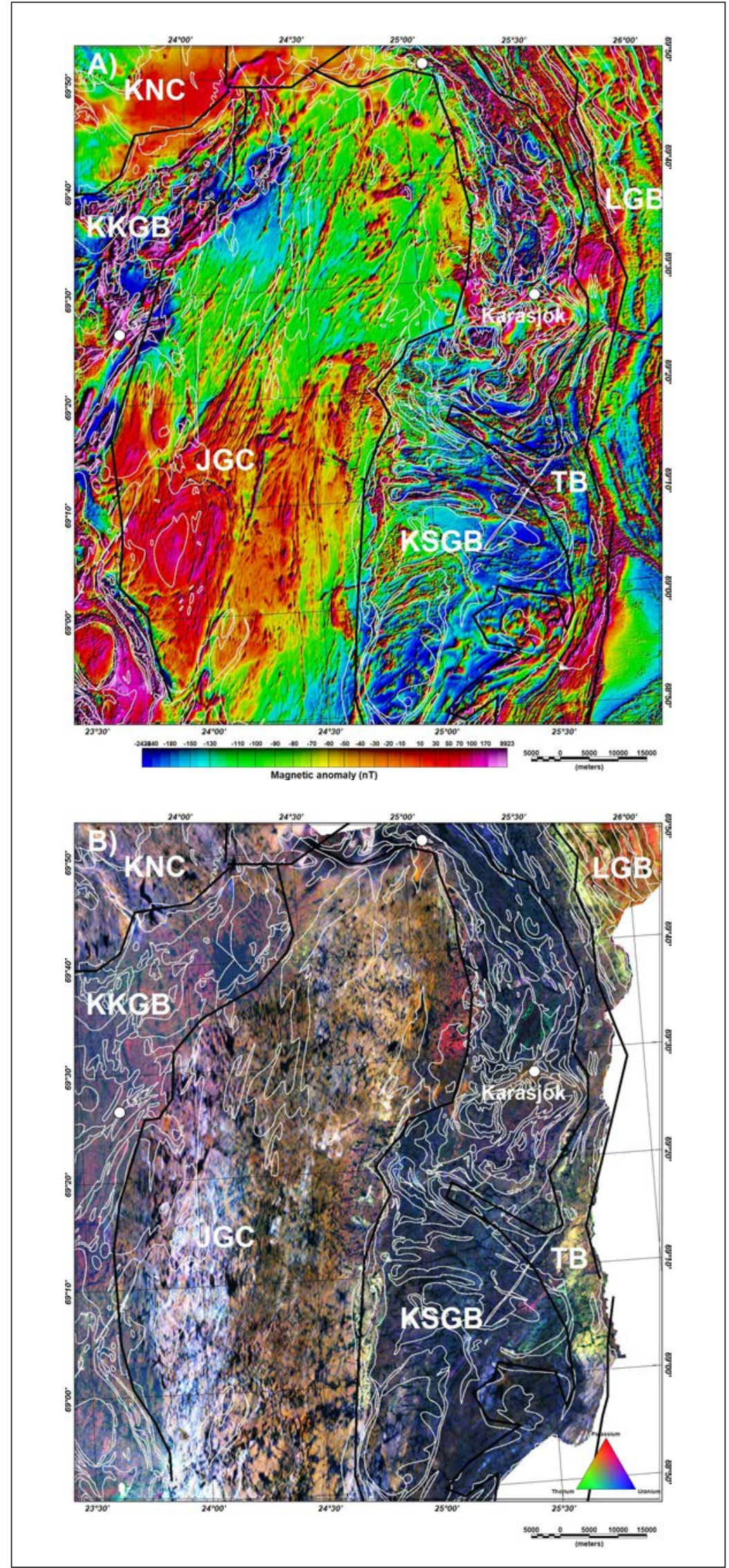

Figure 9. (A) Magnetic data. (B) Ternary map of radiometric data. The solid white lines show the geological boundaries based on the 1:500,000 map of Finnmark. The solid black lines show the approximate boundaries of the major geological terranes. Abbreviations: JGC - Jergol Gneiss Complex, KSGB - Karasjok Greenstone Belt, KNC - Kalak Nappe Complex, KSGB - Karasjok Greenstone Belt, LGB - Lapland Granulite Belt, TB - Tanaelv Belt. 
albite-felsites and graphitic schists, and komatiites are also registered (Olsen \& Nilsen, 1985). Most of the KKGB is covered by reprocessed magnetic and radiometric data from the years 1979-1991 (Fig. 3 \& Table 2). The mafic volcanites record strong magnetic anomaly signals, so much so that the KKGB can easily be traced northnorthwestwards beneath the Caledonian nappes and clearly links up with a comparable volcanosedimentary assemblage in the Alta-Kvænangen Window (Fig. 4; Åm, 1975; Olesen et al., 1990; Henderson et al., 2015). Similar mafic-dominated assemblages occur northeast of Altafjorden in the Altenes and Repparfjord tectonic windows (Fareth, 1979; Pharaoh et al., 1983; Torgersen, 2015), and it is quite clear that the positive magnetic anomalies can be traced continuously from the KKGB to the Repparfjord window. In addition to the highmagnetic anomalies of the greenstones, a very prominent low-magnetic, oval-shaped anomaly is distinguishable which is related to quartzites and sandstones of the Masi formation in the Addjit anticline (Fig. 4; Olesen \& Sandstad, 1993). On the ternary map the KKGB is appreciably brighter than the Karasjok Greenstone Belt (KSGB). This is surprising considering that greenstones dominate in both belts. However, the radioelement concentration values of the KKGB might be artificially higher due to the limitations of the reprocessing (Figs. 6 \& 7; Dumais, 2014).

The Raiseatnu Complex (RGC) (Fig 2) to the west of the KKGB is characterised by magnetic anomalies trending NNW-SSE. This is different from the JGC and furthermore the RGC is more similar to the KKGB in terms of the greater number of anomalies and also their shapes. This gneiss complex shows short-wavelength and circular anomalies compared to the more subdued and smoother anomaly pattern of the JGC (Fig. 4; see also Olesen \& Sandstad, 1993; Henderson et al., 2015). The granitic gneisses of the RGC range in age from $c .1870$ to $1830 \mathrm{Ma}$ (Bingen et al., 2015).

Rocks of a comparable age to those on Finnmarksvidda occur on islands in western Troms in the horstlike culmination termed the West Troms Basement Complex (WTBC) (Fig. 2; Zwaan, 1995; Bergh et al., 2007, 2010). Several NNW-SSE-trending shear zones and shear belts dissect the WTBC and can be followed inland beneath the Caledonian thrust sheets into the Svecofennian province of northern Sweden and Finland. The basement architecture of the WTBC can also be followed offshore with the aid of high-resolution bathymetric data (Indrevær et al., 2013; Indrevær \& Bergh, 2014). The WTBC is covered mainly by the new TROFI W-C 14 aeromagnetic surveys (area 4 in Fig. 3 $\&$ Table 1) which have a larger line spacing as compared with the other parts of the study area. Because of this, magnetic anomalies appear smoother and there are fewer magnetic features in general. Nevertheless, these data do show the link between onshore and offshore structures, and also the continuation of the structures and anomalies beneath the Caledonian thrust sheets. In addition to the TROFI survey, two areas have been measured by helicopter with denser line spacings and lower altitudes on the islands of Ringvassøya, Senja and Vanna (Table 2 \& Fig. 3). These three islands are the only places in the WTBC where radiometric data have been measured (Figs. 3 \& 10). Vanna island shows a distinctive reddish colour on the ternary map (Fig. 10D) signifying a very high content of potassium. This is ascribed to the presence of tonalitic, granodioritic and granitic rocks which are also exposed in the northeast of Ringvassøya. The eastern and northwestern parts of Ringvassøya show very high levels of thorium and to a lesser extent potassium and uranium (Fig. 10D). The tonalite-trondhjemite-granodiorite (TTG) orthogneisses in the age range 2.9-2.6 Ga characterise the Neoarchaean basement, with a cover sequence dating to 2.4-2.2 Ga on Vanna (Bergh et al., 2007). Other belts of supracrustal rocks are present and diverse Palaeoproterozoic, felsic, mafic and ultramafic plutonic rocks $(2.4-1.7 \mathrm{Ga})$ penetrate the entire terrane (Corfu et al., 2003; Bergh et al., 2010; Myhre et al., 2013). Neoarchaean metasupracrustal rocks constitute the Ringvassøya greenstone belt (RGB) (Motuza et al., 2001) which is similar to the KSGB and the KKGB in terms of radioactivity. It apparently contains negligible amounts of Th, $\mathrm{K}$ and $\mathrm{U}$ (Figs. $7 \& 10 \mathrm{D}$ ). This is very well defined by the dark colour in the ternary map and in the individual concentration maps of Th, $\mathrm{K}$ and $\mathrm{U}$. The WTBC is bordered to the southwest - outside our study area - by the anorthosite-mangerite-charnockitegranite suite of Vesterålen and Lofoten (Griffin et al., 1978).

Taking the Neoarchaean and Palaeoproterozoic terranes of eastern Finnmark and western Troms as a whole, all are characterised by complex, polyphasal, tectonothermal and magmatic histories. With the exception of the Sørvaranger-Kola Terrane, all the other basement complexes and belts were ultimately affected by the composite Svecofennian orogeny (c. 1.92-1.79 $\mathrm{Ga}$ ) (Lahtinen et al., 2008). These orogenic pulses are not directly relevant to this present contribution, but detailed descriptions can be found in many of the publications cited above.

The Caledonian front in Finnmark and Troms is marked by a thin sequence of Late Neoproterozoic to Cambrian sedimentary rocks known as the Dividal Group. The succession rests unconformably on the Precambrian crystalline basement and consists mainly of sandstones and shales with local diamictite (Føyn, 1967). The Caledonian front is also recognisable by the considerable change in magnetic signature from the older Precambrian crystalline basement to the Caledonian nappes. The metasedimentary rocks of the Caledonian nappes generally have very low susceptibilities (Olesen et al., 2010) and thus appear transparent to the underlying magnetic rocks. An older, wholly Neoproterozoic, 

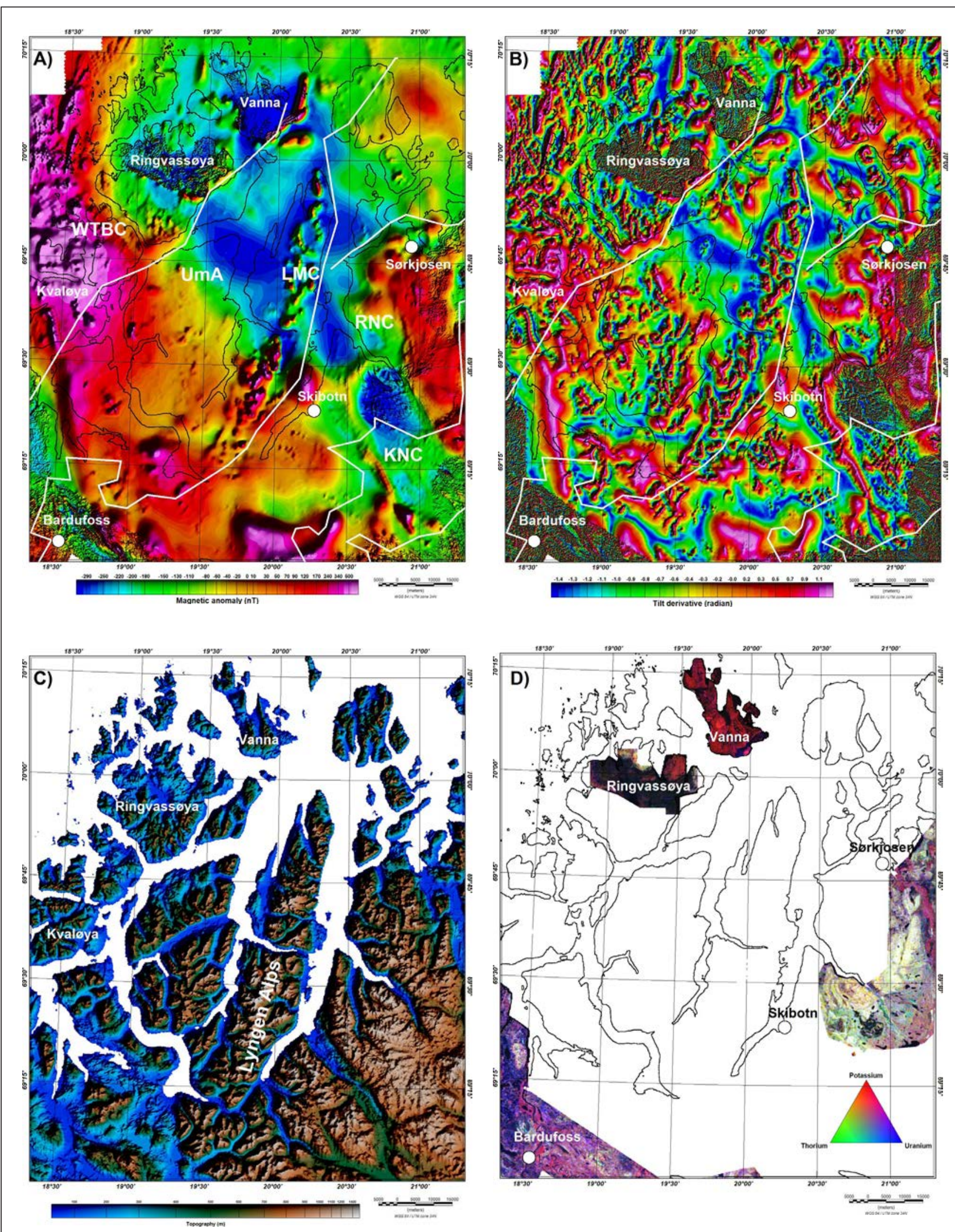

Figure 10. The western Troms region, including the WTBC. (A) Magnetic data. (B) Tilt-derivative map. (C) Topography map. (D) Radiometric ternary map. The white solid lines show the approximate boundaries of the major geological terranes. Abbreviations: KNC - Kalak Nappe Complex, LMC - Lyngen Magmatic Complex, RNC - Reisa Nappe Complex, UmA - Uppermost Allochthon in northern and central Troms, WTBC - West Troms Basement Complex. 
autochthonous succession in SE Varanger Peninsula is termed the Vadsø Group. The GNC, lying with thrust contact directly above the Dividal Group in Finnmark, comprises low-grade metasedimentary formations of Cryogenian to Tremadocian age, and of fluvial to shallow-marine shelfal origin. As previously mentioned, some of the older terranes on the shield (e.g., LGB) can be traced quite clearly underneath the GNC using the aeromagnetic data (Fig. 8A). Two prominent glacial diamictite formations of Ediacaran age are also present (Edwards, 1984). Platformal sandstones and shales also occur in southern Finnmark in the Tierte Nappe (Zwaan \& Roberts, 1978), and around the Mauken Window in southern Troms as part of the Målselv Nappe (Zwaan et al., 1998; Bjerkgård et al., 2015).

The thick lithological successions in the Laksefjord and Kalak nappe complexes of the Middle Allochthon show evidence of similar depositional histories during the Neoproterozoic era, with cross-bedded, fluvial sandstones giving way northwards to alternating shallowmarine psammites and pelites and then to deepermarine, graded-bedded turbidites in the far north. An interesting feature is that many of the basal bedding surfaces and foresets in the fluvial and marine sandstones are enriched in heavy minerals, especially magnetite and titanomagnetite, giving the rocks a distinctive stripy appearance (Roberts, 2007). These magnetic signatures are clearly revealed in our high-resolution magnetometry data (Fig. 11B, C). These sandstones show similar magnetic lineaments to enclosed Ediacaran metadolerites dykes, the latter being broadly parallel to bedding after deformation and rotation, but these dyke anomalies are less continuous (Nasuti et al., 2015).

The highest Sørøy-Seiland Nappe in the KNC (Fig. 2) includes the mainly ultramafic and mafic rocks of the SIP (Robins \& Gardner, 1975; Robins, 1982, 1996; Bennett et al., 1986), which also contains carbonatites (Heier, 1961; Sturt \& Ramsay, 1965). These plutonic rocks have been dated to around 570-560 Ma (Roberts et al., 2006). Mafic dykes now in the form of deformed metadolerites noted above are common throughout the KNC and locally in the LNC and are considered to represent a major phase of Ediacaran rifting that occurred along the outer Baltoscandian margin of Baltica. In Troms, a tholeiitic mafic dyke swarm in one nappe at the top of the KNC has been dated to $580 \mathrm{Ma}$ (Zwaan \& van Roermund, 1990). These dykes can be delineated by the new aeromagnetic data (Fig. 4) where the data have sufficient resolution for a certain dyke thickness. For example, if the dykes have a thickness of 2-10 $\mathrm{m}$ but the aeromagnetic line spacings are about $500 \mathrm{~m}$ (TROFI W-C; Table 1), we are not able to map the dykes. However, it is possible to see the result of a combination of magnetic responses from several closely spaced dykes as a single linear feature, as for example in the north of Varanger Peninsula (Nasuti et al., 2015).
Within the KNC there are three tectonic windows in which are exposed Early Palaeoproterozoic, volcanosedimentary successions generally known as the Raipas Supergroup that have been traced from and broadly correlated with comparable successions in the Kautokeino Greenstone Belt (Åm, 1975; Olesen et al., 1990). As described earlier, the positive magnetic anomalies of the KKGB can be followed northnorthwestwards beneath the thin Kalak allochthon and link up with similar, mafic volcanite-dominated successions in the Alta-Kvænangen Window (Fig. 4). The magnetic anomalies, in concert with the geological units, then swing clockwise into a more NE-SW trend close to Alta, and can easily be followed across the narrow fjord into the small Altenes Window (Fareth, 1979) and farther northeastwards into the Repparfjord Window (Reitan, 1963; Pharaoh et al., 1983; Torgersen, 2015; Torgersen et al., 2015). Based on our highresolution aeromagnetic data, there can be little doubt that these diverse volcano-sedimentary successions of the Raipas Supergroup can be traced from window to window (Fig. 4), and are thus distant relations of the KKGB. The above-mentioned, major, right-angle swing in trend has been interpreted as relating to a gradually increasing Caledonian allochthoneity from a more or less parautochthonous Alta-Kvænangen Window to a largely allochthonous Repparfjord Window (Gayer et al., 1987; Olesen et al., 1990). This clockwise rotation and uplift is suggested to have been broadly concurrent with the thrust-emplacement and subsidence of the SIP and Sørøy-Seiland Nappe, most likely during the Silurian, Scandian event (e.g., Dallmeyer et al., 1988; Olesen et al., 1990).

The Upper Allochthon in our study area is represented by the Magerøy Nappe (MN) in northern Finnmark and the Reisa Nappe Complex (RNC) (Fig. 2) in Troms. The metasedimentary succession in the Magerøy Nappe on Magerøya is of Early Silurian age based on fossil evidence. The oldest formations are mainly of shallow-marine origin and are succeeded by a distinctive turbiditic, flysch sequence (Andersen, 1984). The latter also occurs in imbricate thrust slices on the mainland and on Sørøya (Kirkland et al., 2005; Corfu et al., 2006). Scandian deformation commenced shortly after the flysch deposition and was interrupted by intrusion of mainly ultramafic and mafic plutons of the late Early Silurian Honningsvåg Igneous Complex (Robins, 1998; Corfu et al., 2006). Bodies of granite of similar age are also present elsewhere in the Magerøy Nappe. Palaeomagnetic data from the Honningsvåg Igneous Complex have suggested that the complex and its hostrock succession were probably originally located close to the Laurentian margin (Corfu et al., 2006). The new aeromagnetic data reveal several linear features in the Magerøy Nappe. The most prominent one is clearly related to a NW-SE-trending Carboniferous dyke (Fig. 11; Nasuti et al., 2015). As previously mentioned, the line spacing of the aeromagnetic surveys can limit our 


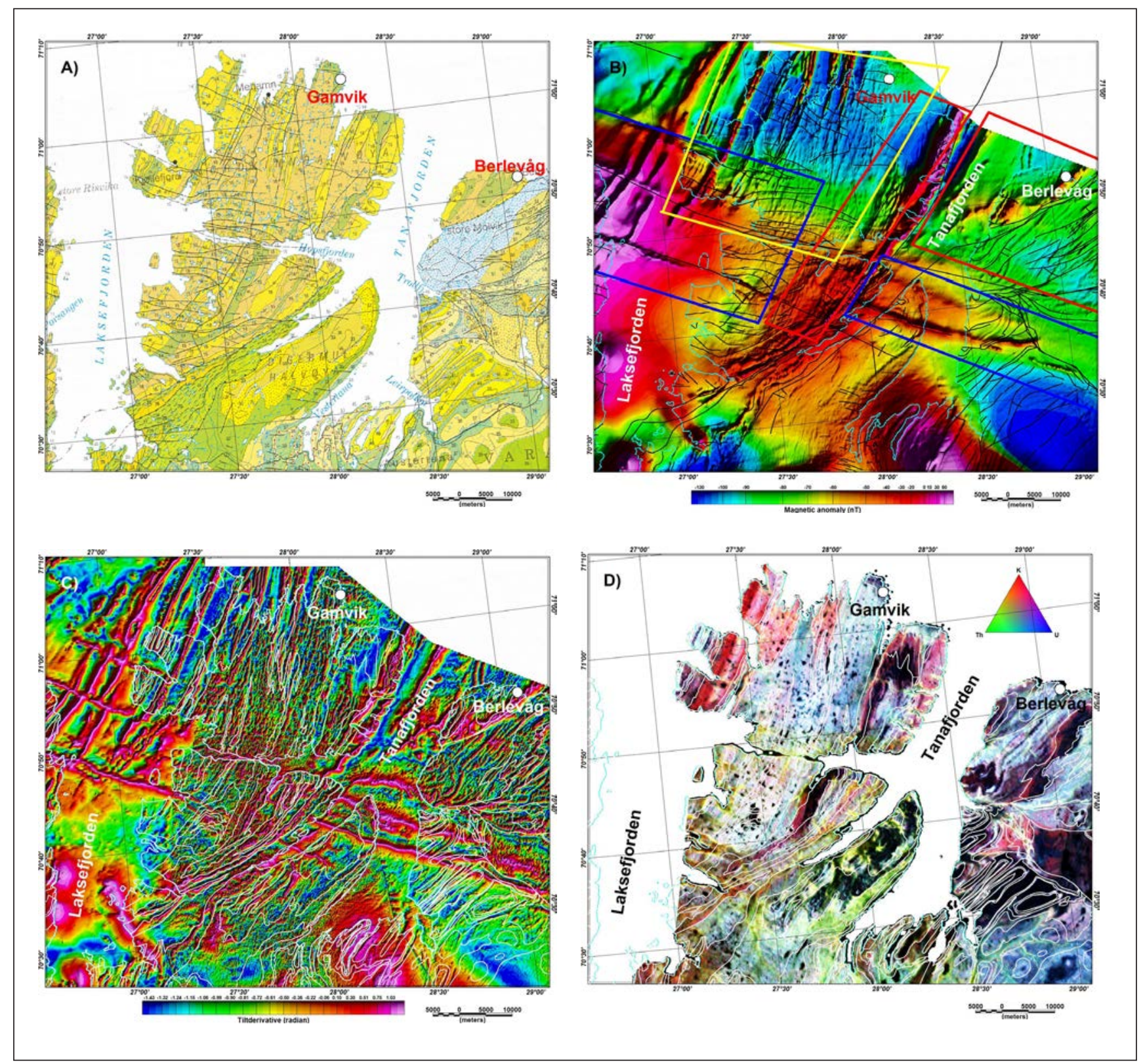

Figure 11. (A) Geological map of the Nordkinn, Digermulen and NW Varanger peninsulas taken from the 1:500,000 scale map of Finnmark county (Siedlecka \& Roberts, 1996). The rocks range in age from Cryogenian to Tremadocian. Colour scheme: yellow - cross-bedded sandstones, pale orange - interbedded sandstones and phyllites, green - pelitic formations, pale blue - sandstones and mudstones. (B) Magnetic anomaly map depicting the different mafic dyke groups. The three discussed dyke groups based on their ages are outlined by coloured boxes (modified from Nasuti et al., 2015). NE-SW to NNE-SSW and ENE-WSW Ediacaran metadolerites (red boxes), NE-SW and also N-S Late Devonian dolerites (green boxes), WNW-ESE Carboniferous dolerites (blue boxes), and interbedded sandstones and phyllites (yellow box). (C) Tilt-derivative of magnetic data. (D) Ternary map of radiometric data. The solid white lines show the geological boundaries based on the 1:500,000 map of Finnmark (Siedlecka \& Roberts, 1996).

observations and interpretations. On Magerøya, the line spacing is $500-1000 \mathrm{~m}$ and consequentlly any thinner dykes or even small faults are not discernible, even though some of them have been mapped on the surface.

The RNC comprises four separate nappes, in ascending order the Vaddas, Tamokdalen, Kåfjord and Nordmannvik nappes (Zwaan, 1988). The second and third nappes are basically repetitions of a thick, amphibolite-facies, lithostratigraphic succession that is most completely developed in the Vaddas Nappe (Lindahl et al., 2005). The five formations in this nappe show a bipartite depositional history. The lowest three formations are of shallow-marine to lagoonal or reefal origin and include a marble member with fossils of Ashgill-Early Llandovery age (Binns \& Gayer, 1980). These units are succeeded by deeper-water sediments including a $c .1 \mathrm{~km}$ thickness of turbidites and also a metabasalt member, locally with associated massive sulphide deposits, which attains a maximum 
thickness of $600 \mathrm{~m}$ (Lindahl et al., 2005). This upper volcanosedimentary unit was ultimately intruded by tholeiitic gabbros of Silurian age. Thus, the overall depositional and magmatic development, except for the submarine basalts, is similar to that in the Magerøy Nappe, as well as in the correlative Köli Nappe Complex farther to the south in Sweden. The Nordmannvik Nappe, at the top of the RNC, is composed mostly of high-grade kyanite and sillimanite schists, gneisses and migmatites with lensoid marble layers, all of which are strongly blastomylonitic (Andresen et al., 1985). Some parts of the RNC are covered by high-resolution heliborne data which have enabled us to delineate very fine structural details. These data include both aeromagnetic and radiometric measurements (Fig. 10A, D).

The Uppermost Allochthon in northern and central Troms (UmA) (Fig. 1) is represented by three main tectonic units, in ascending order the Lyngsfjell, Nakkedal and Tromsø nappes (Zwaan et al., 1998). The Lyngsfjell Nappe comprises the ophiolitic Lyngen Magmatic Complex (LMC) (Selbekk et al., 1998; Kvassnes et al., 2004) and unconformably overlying, greenschist-facies Balsfjord Group (Minsaas \& Sturt, 1985). A tonalite in a sheared metabasalt in the LMC (Fig. 2) has yielded a $\mathrm{U}-\mathrm{Pb}$ zircon age of $469 \pm 5 \mathrm{Ma}$ (Oliver \& Krogh, 1995). The LMC is a distinctive feature in the aeromagnetic data with strong positive anomalies (Fig. 10A, B). However, the magnetic anomalies within the LMC are not linked together but appear to be isolated. On the geological map the whole of the LMC is shown as one major unit but the aeromagnetic data shows this to comprise several positive magnetic anomalies separated by low magnetic areas. This is due to the high mountains in the 'Lyngen Alps' and also the altitude flown in the survey. The magnetic anomalies simply follow the topography and in some areas there is a one-to-one correlation (Fig. 10B, C) It is also noteworthy and a curiosity that similar magnetic anomalies can be followed directly south of the LMC into a hilly area which is in the RNC below the Lyngsfjell Nappe. Higher up in the Balsfjord Group succession, metalimestones contain corals and brachiopods indicative of a Late Ordovician to Early Silurian age (Binns \& Matthews, 1981; Bjørlykke \& Olaussen, 1981). On Senja, sedimentary rocks of the Lyngsfjell Nappe lie tectonically directly upon Palaeoproterozoic gneisses (Zwaan et al., 1998), implying that the Lower, Middle and Upper allochthons either were never present or have been completely excised in this coastal district. The Nakkedal Nappe is composed largely of amphibolite-facies, quartzofeldspathic gneisses with lenses of amphibolite, and a migmatised gabbro in the Skattøra Migmatite Complex, with an age of migmatisation of $464 \pm 4 \mathrm{Ma}$ (Selbekk et al., 2000). Between Finnsnes and Senja, radiometric data are characterised by intermediate concentration levels of uranium and low concentrations of potassium and thorium, while areas in the west and northwest of Senja show, in contrast, the opposite concentration levels. Aeromagnetic data show a positive magnetic anomaly over the island of Senja (Fig. 4A). There, magnetic lineaments show several different orientations but in general the dominant trends are NW-SE to E-W.

The high-pressure rocks of the overlying Tromsø Nappe include a variety of schists, gneisses, marbles, ultramafic rocks and meta-eclogites (Krogh et al., 1990). Work on the eclogites has revealed two separate UHP events, the early phase dated by Corfu et al. (2003) to $452 \mathrm{Ma}$. The metamorphism in both the Nakkedal and the Tromsø nappes has been suggested to relate to Taconian orogenesis along the eastern margin of Laurentia (Krogh et al., 1990; Roberts et al., 2007). The rocks of the Uppermost Allochthon as a whole have also been considered to derive from the Laurentian side of the Iapetus Ocean (Stephens \& Gee, 1989; Roberts et al., 2002, 2007; Melezhik et al., 2003). Based on radiometric data, the Tromsø Nappe is characterised mainly by intermediate concentration levels of uranium and low concentrations of potassium and thorium associated in part with carbonate rocks. Several circular areas also have high concentrations of thorium and intermediate contents of potassium (Fig. 7).

A large positive magnetic zone elongated NW-SE and thus parallel to the other terranes in eastern Finnmark can also be recognised in the westernmost part of the WTBC. This has been suggested by Olesen et al. (1990) to be part of Transcandinavian Igneous Belt (TIB). This is cross-cutting almost perpendicularly the Caledonian nappes, UMA, RNC and KNC (Figs. 4 \& 10A), and is interpreted to indicate that this NW-SE magnetic zone extends southeastwards beneath the Caledonides. On the TDR map (Fig. 10B), two distinctive large linear anomalies oriented NNW-SSE can be recognised at the southwestern and northeastern limits of this magnetic zone. The southwestern anomaly can be traced to the mapped mafic metavolcanic rocks on Kvaløya. This clearly depicts a continuation of these rocks under the nappes of the Upper and Uppermost allochthons. The northeastern linear anomaly is located to the northeast of Skibotn and can be traced beneath the KNC and the RNC.

The youngest rocks exposed on land in the area of Finnmark and North Troms covered by our highresolution aeromagnetic survey are dolerite dykes of Late Devonian (c. $375 \mathrm{Ma}$ ) and Early Carboniferous (c. 337 $\mathrm{Ma})$ age in the Caledonides of northernmost Finnmark. These dykes represent disparate phases of post-Scandian, rift-related extension and are visible on our aeromagnetic data as spectacular linear, positive, magnetic anomalies, illustrated and discussed in a separate paper in this volume (Nasuti et al., 2015). We refer the reader to this paper for details. 


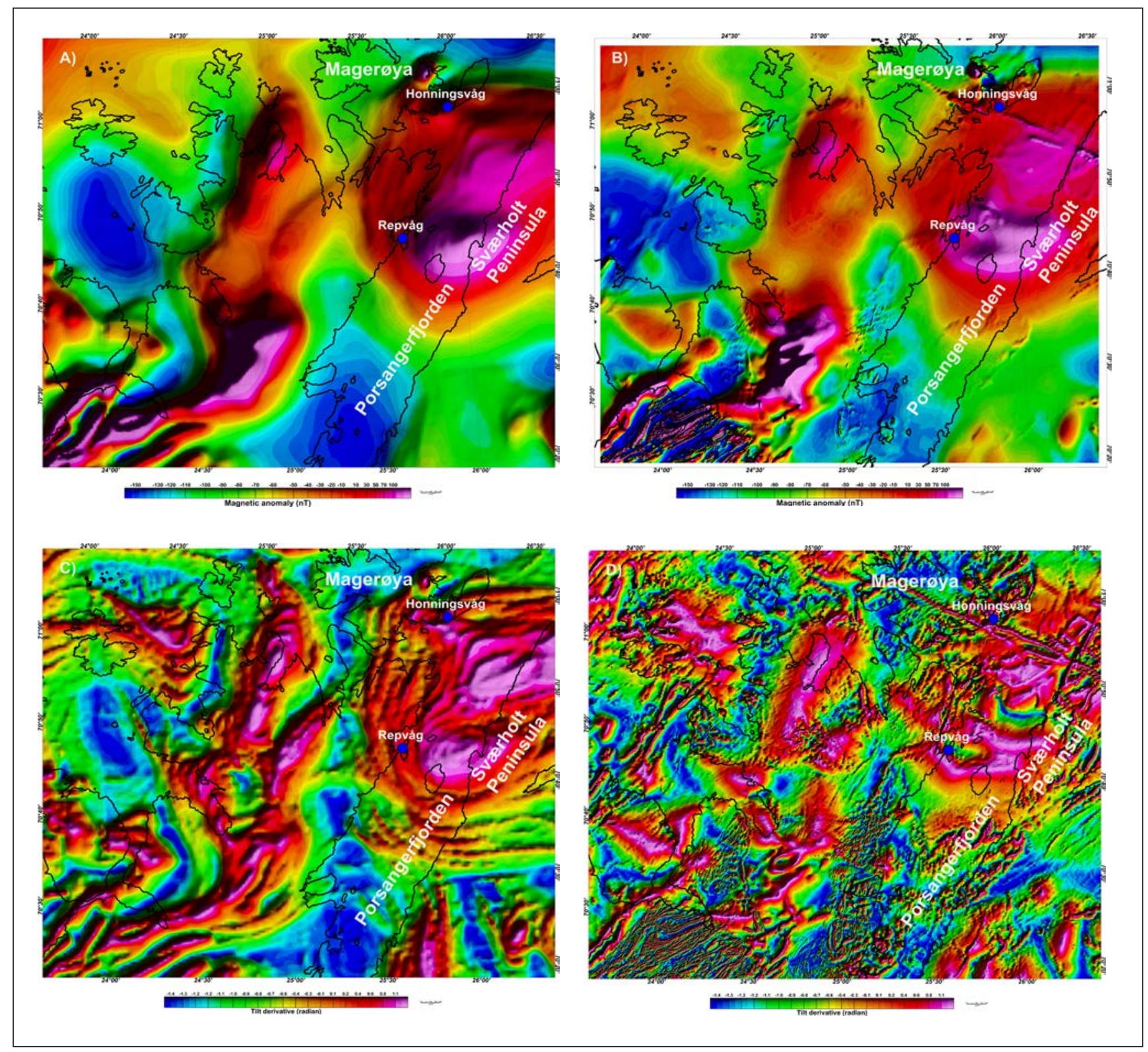

Figure 12. New and vintage magnetic data from the Svorholt-Magerøya region, northwestern Finnmark (see Fig. 4A). (A) Vintage magnetic data. (B) Newly acquired magnetic data. (C) Tilt- derivative map of the vintage magnetic data. (D) Tilt-derivative map of the new magnetic data.

\section{Conclusions}

This paper presents the results of a compilation of the new aeromagnetic and radiometric data collected by the Geological Survey of Norway in Finnmark and Troms, Norway, during the years 2011-2015. The new compilations show a considerably higher quality compared to those based on the pre-existing data (Fig. $12 \mathrm{~A}-\mathrm{D})$. This is mainly due to the use of more sensitive magnetometers and radiometric instruments, denser line-spacing and more accurate navigation, as well as improved processing and data presentation for the new datasets. In addition to the Norwegian database, parts of the databases of North Finland and Sweden have also been compiled and merged in order to obtain a better picture of the geological structures in the border areas. Several high-quality gridded datasets (magnetic anomalies and radiometric maps) have been created. There are several evident applications for the new grids. First, the high-resolution digital datasets present a reliable basis not only for modifying parts of the regional geological maps and characterising the major tectonic units in the region but also provide details that were not visible in the vintage data. These grids are applicable also for the various procedures of quantitative interpretation such as calculations of $3 \mathrm{D}$ inversion, depths to the covered geological structures, and 2D and 3D modelling, 
but these topics are outside the scope of the present contribution.

The new aeromagnetic data in combination with the radiometric concentration maps allow new features to be mapped, especially in the more poorly exposed areas, and raise the need for making adjustments to the existing geological maps. New faults, dykes and other linear features have been revealed as prominent magnetic features. It is noteworthy that the radiometrics clearly facilitate and complement the aeromagnetic data interpretations. As an example, the northernmost part of our study area in and adjacent to the Nordkinn Peninsula shows how the ternary map is able to differentiate between different geological rock units. In general, there is a very good match between the surface geology and radiometrics but in some areas it appears that some rock units could be divided up based on their mineralogical composition. Furthermore, in the area south of Berlevåg (Fig. 11D) the ternary map shows a more complex picture than the geology at this scale (1:500,000; Fig. $11 \mathrm{~A})$, but there is better correspondence at 1:50,000 scale. It is noticeable that although it is difficult to distinguish the same rock units on aeromagnetic maps, it is much easier to detect the geological features such as faults and dykes using magnetic patterns (Fig. 11B, C). In addition, the geological structures can be followed from onshore to offshore using the magnetic data whereas it is impossible to use radiometric data in the fjords, e.g., Tanafjorden and offshore areas. This shows that, despite their independence, these two different methods when used together can assist in the mapping of geological units and structures.

The prolongation of major Archaean-Palaeoproterozoic terranes beneath the Caledonides is now much more clearly defined than previously known. Consequently, the aeromagnetic and radiometric maps of North Norway presented here provide more reliable basic information for further tectonic analysis and estimation of potential mineral resources in the region.

Acknowledgements. This contribution is a major part of the programme 'Mineral Resources in North Norway' (MINN) of the Geological Survey of Norway. We would like to thank Odleiv Olesen as the project leader of the MINN fixed-wing surveys at NGU and Jon Steinar Rønning as the leader of helicopter surveys at NGU. We also thank the Geological Survey of Finland (GTK) and the Geological Survey of Sweden (SGU) for providing the data from their respective countries. Special thanks to Maija Kurimo from GTK for reading the manuscript and suggesting valuable comments. We also thank the two Canadian geophysical companies Noatem Airborne geophysics and EON Geosciences Inc. for the data acquisition. Finally, thanks go to the reviewers, Gerald Gabriel and Tim Pharaoh, for their helpful suggestions and comments that led to improvements in the manuscript.

\section{References}

Airo, M.-L. (ed.) 2005: Aerogeophysics in Finland 1972-2004: Methods, System Characteristics and Applications. Geological Survey of Finland Special Paper 39, 197 pp.

Andersen, T.B. 1984: The stratigraphy of the Magerøy Supergroup, North Norway. Norges geologiske undersøkelse Bulletin 395, 25-37.

Andresen, A., Fareth, E., Bergh, S., Kristensen, S.E. \& Krogh, E. 1985: Review of Caledonian lithotectonic units in Troms, north Norway. In Gee, D.G. \& Sturt, B.A. (eds.): The Caledonide orogen Scandinavia and related areas, John Wiley \& Sons, Chichester, pp. 569-578.

Barbey, P., Covert, J., Martin, H., Moreau, B., Capdevila, R. \& Hameurt, J. 1980: Relationships between granite-gneiss terrains, greenstone belta and granulite belts in the Archaean crust of Lapland (Fennoscandia). Geologische Rundschau 69, 648-658.

Bennett, M.C., Emblin, S.R., Robins, B. \& Yeo, W.J.A. 1986: Hightemperature ultramafic complexes in the North Norwegian Caledonides: I - Regional setting and field relationships. Norges geologiske undersøkelse Bulletin 405, 1-40.

Bergh, S.G., Kullerud, K., Corfu, F., Armitage, P.E.B., Davidsen, B., Johansen, H.W., Pettersen, T. \& Knudsen, S. 2007: Low-grade sedimentary rocks on Vanna, North Norway: a new occurrence of a Palaeoproterozoic (2.4-2.2 Ga) cover succession in northern Fennoscandia. Norwegian Journal of Geology 87, 301-318.

Bergh, S.G., Kullerud, K., Armitage, P.E.B., Zwaan, K.B., Corfu, F., Ravna, E.J.K. \& Myhre, P.I. 2010: Neoarchaean to Svecofennian tectono-magmatic evolution of the West Troms Basement Complex, North Norway. Norwegian Journal of Geology 90, 21-48.

Berthelsen, A. \& Marker, M. 1986: Tectonics of the Kola collision suture and adjacent Archaean and Early Proterozoic terrains in the northeastern region of the Baltic Shield. Tectonophysics 126, 31-55.

Bingen, B., Solli, A., Viola, G., Torgersen, E., Sandstad, J.S., Whitehouse, M.J., Røhr, T.S., Ganerød, M. \& Nasuti, A. 2015: Geochronology of the Palaeoproterozoic Kautokeino Greenstone Belt, Finnmark, Norway: Tectonic implications in a Fennoscandia context. Norwegian Journal of Geology 95, 365-396. http://dx.doi. org/10.17850/njg95-3-09.

Binns, R.E. \& Gayer, R.A. 1980: Silurian or Upper Ordovician fossils at Guolasjav'ri, Troms, Norway. Nature 284, 53-55.

Binns, R.E. \& Matthews, D.W. 1981: Stratigraphy and structure of the Ordovician-Silurian Balsfjord Supergroup, Troms, North Norway. Norges geologiske undersøkelse 365, 39-54.

Bjerkgård, T., Slagstad, T., Henderson, I.H.C., Sandstad, J.S. \& Schönenberger, J. 2015: Geology and gold mineralisation in the Mauken basement window, Målselv, Troms. Norwegian Journal of Geology 95, 423-443. http://dx.doi.org/10.17850/njg95-3-08.

Bjørlykke, A. \& Olaussen, S. 1981: Silurian sediments, volcanics and mineral deposite in the Sagelvvatn area, Troms, North Norway. Norges geologiske undersøkelse 365, 1-38.

Braathen, A. \& Davidsen, B. 2000: Structure and stratigraphy of the Palaeoproterozoic Karasjok Greenstone Belt, north Norway regional implications. Norsk Geologisk Tidsskrift 80, 33-50.

Bugge, J.A.W. 1978: Norway. In Bowie, S.H.U., Kvalheim, A. \& Haslam, H.W. (eds.): Mineral Deposits of Europe, Vol.1 North West Europe, Institute of Mining and Metallurgy and the Mineralogical Society, London, pp. 199-249.

Corfu, F., Ravna, E.J.K. \& Kullerud, K. 2003: A Late Ordovician U-Pb age for the Tromsø Nappe eclogites, Uppermost Allochthon of the Scandinavian Caledonides. Contributions to Mineralogy and Petrology 145, 502-513.

Corfu, F., Torsvik, T.H., Andersen, T.B., Ashwal, L.D., Ramsay, D.M. \& Roberts, R.J. 2006: Early Silurian mafic-ultramafic and granitic plutonism in contemporaneous flysch, Magerøy, northern Norway: $\mathrm{U}-\mathrm{Pb}$ ages and regional significance. Journal of the Geological Society of London 162, 291-301. 
Dallmeyer, R.D., Mitchell, J.G., Pharaoh, T.C., Reuter, A. \& Andresen, A. 1988: K-Ar and ${ }^{40} \mathrm{Ar} /{ }^{39} \mathrm{Ar}$ whole rock ages of slate/phyllite from allochthonous basement and cover in the tectonic windows of Finnmark, North Norway: evaluating the extent and timing of Caledonian tectonothermal activity. Bulletin of the Geological Society of America 100, 1493-1501.

Daly, J.S., Balagansky, V.V., Timmerman, M.J. \& Whitehouse, M.J. 2006: The Lapland-Kola orogen: Palaeoproterozoic collision and accretion of the northern Fennoscandian lithosphere. Geological Society of London Memoirs 32, 579-598.

Dobrzhinetskaya, L.F., Nordgulen, Ø., Vetrin, V.R., Cobbing, J. \& Sturt, B.A. 1995: Correlation of the Archaean rocks between the Sørvaranger area, Norway, and the Kola Peninsula, Russia (Baltic Shield). Norges geologiske undersøkelse Special Publication 7, 7-27.

Dumais, M.-A. 2014: Reprocessing and compilation of radiometrics data from Finnmark and northern Troms. Norges geologiske undersøkelse Report 2014.015, 48 pp.

Dvorak, Z. 1982: DIGHEM II survey of the Finnmark area, Norway for A/S Sydvaranger. Dighem Ltd. Rapport 706, 69 pp.

Edwards, M.B. 1984: Sedimentology of the Upper Proterozoic glacial record, Vestertana Group, Finnmark, North Norway. Norges geologiske undersøkelse Bulletin 394, 76 pp

EON Geosciences Inc. 2015: Troms-Finnmark fixed wing aeromagnetic survey 2014 (TROFI-14). Report EON Geosciences Inc., Montréal, Quebec, Canada, 34 pp.

Fareth, E. 1979: Geology of the Altenes area, Alta-Kvænangen Window, North Norway. Norges geologiske undersøkelse Bulletin 351, 13-30.

Faure, G. 1977: Principles of Isotope Geology. John Wiley and Sons, New York, $464 \mathrm{pp}$.

Føyn, S. 1967: Dividal-gruppen (Hyolithus-sonen) i Finnmark og dens forhold til de eokambrisk-kambriske formasjoner. Norges geologiske undersøkelse 249, 1-82.

Gaál, G., Berthelsen, A., Gorbatschev, R., Kesola, R., Lehtonen, M.I., Marker, M. \& Raase, P. 1989: Structure and composition of the Precambian crust along the POLAR Profile in the northern Baltic Shield. Tectonophysics 162,1-25.

Gayer, R.A., Rice, A.H.N., Roberts, D., Townsend, C. \& Welbon, A. 1987: Restoration of the Caledonian Baltoscandian margin from balanced cross-sections: the problem of excess continental crust. Transactions of the Royal Society of Edinburgh: Earth Sciences 78, 197-217.

Gernigon, L. \& Brönner, M. 2012: Late Palaozoic architecture an evolution of the uthwestern Barents Sea: insights from a new generation of magnetic data. Journal of the Geological Society of London 169, 449-459.

Gernigon, L., Brönner, M., Roberts, D., Olesen, O., Nasuti, A. \& Yamasaki, T. 2014: Crustal and basin evolution of the southwestern Barents Sea: from Caledonian orogeny to continental breakup. Tectonics 33. doi:10.1002/2013TC003439.

Griffin, W.L., Taylor, P.N., Hakkinen, P.N., Heier, K.S., Iden, J.K., Krogh, E.J., Malm, O., Olsen, K.J., Ormaasen, D.E. \& Tveten, E. 1978: Crustal evolution in Lofoten-Vesterålen, Norway, 2700-400 m.y. B.P. Journal of the Geological Society of London 135, 629-647.

Heier, K.S. 1961: Layered gabbro, hornblendite, carbonatite and nepheline syenite on Stjernøy, North Norway. Norsk Geologisk Tidsskrift 41, 109-155.

Heilimo, E., Halla, J., Lauri, L., Rämö, T., Huhma, H., Kurhila, M. \& Front, K. 2009. The Paleoproterozoic Nattanen type granites in northern Finland and vicinity - postcollisional oxidized A-type suite. Bulletin of the Geological Society of Finland 81, 7-38.

Heinrich, E.W. 1958: Mineralogy and Geology of Radioactive raw materials. Mcgraw-Hill, Toronto, London, $654 \mathrm{pp}$.

Henderson, I.H.C., Viola, G. \& Nasuti, A. 2015: A new tectonic model for the Palaeoproterozoic Kautokeino Greenstone Belt, northernNorway, based on high-resolution airborne magnetic data and field structural analysis and implications for mineral potential. Norwegian Journal of Geology 95, 339-363. http://dx.doi. org/10.17850/ njg95-3-05.
Håbrekke, H. 1979: Magnetiske-, elektromagnetiske-, radiometriskeog VLF-målinger fra helikopter over et område syd for Kautokeino. Norges geologiske undersøkelse Report 1734, 12 pp.

Håbrekke, H. 1980a: Magnetiske-, elektromagnetiske-, VLF- og radiometriske målinger fra helikoper over Kautokeino. Norges geologiske undersøkelse Report 1782, 12 pp.

Håbrekke, H. 1980b: Magnetiske-, elektromagnetiske-, VLF- og radiometriske målinger fra helikopter over Bidjovaggeområdet. Norges geologiske undersøkelse Report 1783, 12pp.

Håbrekke, H. 1981: Magnetiske-, elektromagnetiske-, VLF-og radiometriske målinger fra helikopter over konsesjonsområdet ved Bidjovagge. Norges geologiske undersøkelse Report 1833, 12 pp.

Håbrekke, H. 1983a: Geofysiske målinger fra helikopter over et område rundt Masi tett- sted i K. Norges geologiske undersøkelse Report 1902/A, 15 pp.

Håbrekke, H. 1983b: Geofysiske målinger fra helikopter over et område rundt Masi tett- sted i K. Norges geologiske undersøkelse Report 1902/B, 15 pp.

Håbrekke, H. 1984: Geofysiske målinger fra helikopter over kartbladene Carajavrre og Jiesjavrre. Norges geologiske undersøkelse Report 84.006, 15 pp.

Håbrekke, H. 1985: Geofysiske målinger fra helikopter over deler av kartbladene Jiesjav'ri, Bæivasgieddi, Galmatskaidi, Noarvas og Basevuovdi, Finnmark fylke. Norges geologiske undersøkelse Report $84.164,18 \mathrm{pp}$

Håbrekke, H., Mogaard, J.O. \& Rønning, S. 1990: Geofysiske målinger fra helikopter over deler av kartblad Siebe, Finnmark fylke 1989. Norges geologiske undersøkelse Report 89.143, 25 pp.

Indrevær, K. \& Bergh, S.G. 2014: Linking onshore-offshore basement rock architecture and brittle faults on the submerged strandflat along the SW Barents Sea margin, using high-resolution (5 x $5 \mathrm{~m}$ ) bathymetry data. Norwegian Journal of Geology 94, 1-34.

Indrevær, K., Bergh, S.G., Koehl, J.-B., Hansen, J.-A., Schermer, E.R. \& Ingebrigtsen, A. 2013: Post-Caledonian brittle fault zones on the hyperextended SW Barents Sea margin: new insights into onshore and offshore margin architecture. Norwegian Journal of Geology 93, 167-188.

Karpuz, M.R., Roberts, D., Moralev, V.M. \& Terekhov, E. 1995: Regional lineaments of eastern Finnmark, Norway, and the western Kola Peninsula, Russia. Norges geologiske undersøkelse Special Publication 7,121-135.

Kirkland, C.L., Daly, J.S. \& Whitehouse, M.J. 2005: Early Silurian magmatism and the Scandian evolution of the Kalak Nappe Complex, Finnmark, Arctic Norway. Journal of the Geological Society of London 162, 985-1003.

Koistinen, T., Stephens, M. B., Bogatchev, V., Nordgulen, Ø., Wennerström, M. \& Korhonen, J. (comp.) 2001. Geological map of the Fennoscandian Shield, scale 1:2 000 000. Trondheim: Geological Survey of Norway, Uppsala: Geological Survey of Sweden, Moscow: Ministry of Natural Resources of Russia, Espoo: Geological Survey of Finland.

Koslov, N.E., Avedisyan, A.A., Balashov, Y.A., Ivanov, A.A., Kamenskaya, A.D., Mukhamedova, I.V., Polyakova, V.A., Pripachkin, V.A., Rispolozhensky, Y.A. \& Tarnovetsky, L.L. 1995: Some new aspects of geology, deep structure, geochemistry and geochronology of the Lapland Granulite Belt, Baltic Shield. Norges geologiske undersøkelse Special Publication 7, 157-166.

Krogh, E.J., Andresen, A., Byhni, I., Broks, T.M. \& Kristensen, T.M. 1990: Eclogites and polyphase P-T cycling in the Caledonian Uppermst Allochthon in Troms, northern Norway. Journal of Metamorphic Geology 8, 289-309.

Kurimo, M. 2007: Airborne Geophysical Survey Finnmark, Norway. Geological Survey of Finland Report Technical report 2007, 50 pp.

Kurimo, M. 2008: Airborne Geophysical Survey Skuvvanvarri Finnmark. Geological Survey of Finland Report 2008, 41 pp.

Kurimo, M. 2009: Airborne Geophysical Survey Russevatna and Gosjohka Finnmark, Norway. Geological Survey of Finland Report $2009,55 \mathrm{pp}$. 
Kvassnes, A.J.S., Strand, A.H., Moen-Eikeland, H. \& Pedersen, R.B. 2004: The Lyngen Gabbro. the lower crust of an Ordovician incipient arc. Contributions to Mineralogy and Petrology 148, 358-379.

Lahtinen, R., Garde, A.A. \& Melezhik, V.A. 2008: Paleoproterozoic evolution of Fennoscandia and Greenland. Episodes 31, 20-28.

Lehtinen, M., Nurmi, P. A. \& Rämö, O. T. (eds.) 2005. Precambrian Geology of Finland. Key to the Evolution of the Fennoscandian Shield. Developments in Precambrian Geology 14. Elsevier Science B.V. 736 pp.

Levchenkov, O.A., Levsky, L.K, Nordgulen, Ø., Dobzhinetskaya, L.F., Vetrin, V.R., Cobbing, J., Nilsson, L.P. \& Sturt, B.A. 1995: U-Pb zircon ages from Sørvaranger,Norway, and the western part of the Kola Peninsula, Russia. Norges geologiske undersøkelse Special Publication 7, 29-47.

Lindahl, I., Stevens, B.P.J. \& Zwaan, K.B. 2005: The geology of the Váddás area, Troms: a key to our understanding of the Upper Allochthon in the Caledonides of northern Norway. Norges geologiske undersøkelse Bulletin 445, 5-43.

Marker, M. 1985: Early Proterozoic (c. 2000-1900 Ma) crustal structure of the northeastern Baltic Shield: tectonic division and tectogenesis. Norges geologiske undersøkelse Bulletin 403, 55-74.

Melezhik, V.A. \& Sturt, B.A. 1994: General geology and evolutionary history of the Early Proterozoic Polmak-Pasvik-PechengaImandra/Varsuga-Ust'Ponoy greenstone belt in the northeastern Baltic Shield. Earth-Science Reviews 36, 205-241.

Melezhik, V.A., Zwaan, K.B., Motuza, G., Roberts, D., Solli, A., Fallick, A.E., Gorokhov, I.M. \& Kusnetsov, A.B. 2003. New insights into the geology of high-grade Caledonian marbles based on isotope chemostratigraphy. Norwegian Journal of Geology 83, 209-242.

Melezhik, V.A., Bingen, B., Sandstad, J.S., Pokrovsky, B.G., Solli, A. \& Fallick, A.E. 2015: Sedimentary-volcanic successions of the Alta-Kvænangen Tectonic Window in the northern Norwegian Caledonides: Multiple constraints on deposition and correlation with the Fennoscandian Shield. Norwegian Journal of Geology 95, 245-284. http://dx.doi.org/10.17850/njg95-3-01.

Meriläinen, K. 1976: The granulite complex and adjacent rocks in Lapland, northern Finland. Geological Survey of Finland Bulletin 281, 1-129.

Midtun, R.D. 1988: Karasjokgrønnsteinbeltet: Regional geofysisk og geologisk tolkning. Norges geologiske undersøkelse Bulletin 88, 19 pp.

Miller, H.G. \& Singh, V. 1994: Potential-field tilt - a new concept for location of potential-field sources. Journal of Applied Geophysics 32, 213-217.

Minsaas, O. \& Sturt, B.A. 1985: The Ordovician-Silurian clastics sequence overlying the Lyngen gabbro complex, and its environmental significance. In Gee, D.G. \& Sturt, B.A. (eds.): The Caledonide orogen - Scandinavia and related areas, John Wiley \& Sons, Chichester, pp. 379-393.

Mogaard, J.O. \& Skilbrei, J.R. 1986: Geofysiske målinger fra helikopter over kartbladene Kautokeino, Lappoloubba. Norges geologiske undersøkelse Report 86.054, 21 pp.

Mogaard, J.O. \& Mauring, E. 2002: Data Acquisition and Processing - Helicopter Geophysical Survey, Ringvassøy. Norges geologiske undersøkelse Report 2002.099, 9 pp.

Moore, G. 2008: Finland's national airborne geophysical mapping programme and the ' 3 -in-1' approach. First Break 26, Special Topic on Airborne Geophysics, 1-7.

Motuza, G., Motuza, V., Beliatsky, B. \& Savva, E. 2001: The Ringvassøya greenstone belt (Tromso, North Norway): implications for a Mesoarchaean subduction zone. EUROPROBE time-slice symposium "Archaean and Proterozoic Plate Tectonics: Geological and Geophysical Records", 1 October-3 November, St. Petersburg, Russia, pp. 43-44.

Myhre, P.I., Corfu, F., Bergh, S.G. \& Kullerud, K. 2013: U-Pb geochronology along an Archaean geotransect in the West Troms Basement Complex, North Norway. Norwegian Journal of Geology $93,1-24$.
Nasuti, A., Roberts, D. \& Gernigon, L. 2015: Multiphase mafic dykes in the Caledonides of northern Finnmark revealed by a new highresolution aeromagnetic dataset. Norwegian Journal of Geology 95, 285-297. http://dx.doi.org/10.17850/njg95-3-02.

Novatem 2012: Fixed wing magnetic and radiometric survey of the coastal area of Northwestern Norway (FRAS-E). Report no. C11089, Novatem Airborne Geophysics, Mont-Saint Hilaire, Quebec, Canada, 36 pp.

Novatem 2014: Fixed wing magnetic and radiometric survey over the Troms-Finnmark region in Northern Norway (TROFI-14 E). Report no. C14104, Novatem Airborne Geophysics, Mont-Saint Hilaire, Quebec, Canada, 29 pp.

Ofstad, F. 2015a: Helicopter-borne magnetic and radiometric geophysical survey in Dividalen, Målselv municipality, Troms County. Norges geologiske undersøkelse Report 2015.003, 25 pp.

Ofstad, F. 2015b: Helicopter-borne magnetic and radiometric geophysical survey in Øvre Dividalen. Norges geologiske undersøkelse Report 2015.071,29 pp.

Ofstad, F. \& Stampolidis, A. 2014: Helicopter-borne magnetic and radiometric geophysical survey in the Altevann area, Bardu and Målselv Municipalities, Troms. Norges geologiske undersøkelse Report 2014.009, 24 pp.

Ofstad, F., Baranwal, V., Koziel, J., Lynum, R. \& Rodionov, A. 2013: Helicopter-borne magnetic, electromagnetic and radiometric geophysical survey in Repparfjord area, Alta and Kvalsund, Finnmark. Norges geologiske undersøkelse Report 2013.027, 25 pp.

Olesen, O. \& Solli, A. 1985: Geophysical and geological interpretation regional structures within the Precambrian Kautokeino Greenstone Belt, Finnmark, North Norway. Norges geologiske undersøkelse Bulletin 403, 119-133.

Olesen, O. \& Sandstad, J.S. 1993: Interpretation of the Proterozoic Kautokeino Greenstone Belt, Finnmark, Norway from combined geophysical and geological data. Norges geologiske undersøkelse Bulletin 425, 43-64.

Olesen, O., Roberts, D., Henkel, H., Lile, O.B. \& Torsvik, T.H. 1990: Aeromagnetic and gravmetric interpretation of regional structural features in the Caledonides of West Finnmark and North Troms, northern Norway. Norges geologiske undersøkelse Bulletin 419, 1-24.

Olesen, O., Ebbing, J., Gellein, J., Gernigon, L., Koziel, J., Lauritsen, T., Mykelbust, R., Pascal, C., Sand, M., Solheim, A. \& Usov, S. 2010: New aeromagnetic and gravity compilations from Norway and adjacent areas - methods and applications. In Vining, B.A. \& Pickering, S.C. (eds.): Petroleum geology: from mature basins to new frontiers, Geological Society of London 7, 559-586.

Oliver, G.J.H. \& Krogh, T.E. 1995: U-Pb zircon age of $469 \pm 5 \mathrm{Ma}$ from a metatonalite from the Kjosen Unit of the Lyngen magmatic complex, northen Norway. Norges geologiske undersøkelse Bulletin 428, 27-32.

Olsen, K.I. \& Nilsen, K.S. 1985: Geology of the southern part of the Kautokeino Greenstone Belt: $\mathrm{Rb}-\mathrm{Sr}$ geochronology and geochemistry of associated gneisses and late intrusions. Norges geologiske undersøkelse Bulletin 403, 131-160.

Pharaoh, T.C., Ramsay, D.M. \& Jansen, Ø. 1983: Stratigraphy and structure of the northern part of the Repparfjord-Komagfjord window, northern Norway. Norges geologiske undersøkelse Bulletin 377, 45 pp.

Reitan, P.H. 1963: The geology of the Komagfjord tectonic window of the Raipas suite, Finnmark, Norway. Norges geologiske undersøkelse 221,71 pp.

Roberts, D. 2007: Palaeocurrent data from the Kalak Nappe Complex, northern Norway: a key element in models of terrane affiliation. Norwegian Journal of Geology 87, 319-328.

Roberts, D. \& Gee, D.G. 1985: An introduction to the structure of the Scandinavian Caledonides. In Gee, D.G. \& Sturt, B.A. (eds.): The Caledonide orogen - Scandinavia and related areas, John Wiley \& Sons, Chichester, pp. 55-68.

Roberts, D., Olesen, O. \& Karpuz, M.R. 1997: Seismo- and neotectonics in Finnmark, Kola Peninsula and the southern Barents Sea. Part 1: Geological and neotectonic framework. Tectonophysics 270, 1-13. 
Roberts, D., Melezhik, V.A. \& Heldal, T. 2002: Carbonate formations and early NW-directed thrusting in the highest allochthons of the Norwegian Caledonides - evidence of a Laurentian ancestry. Journal of the Geological Society of London 159, 1-5.

Roberts, R.J., Corfu, F., Torsvik, T.H., Ashwal, L.D. \& Ramsay, D.M. 2006: Short-lived mafic magmatism at 560-570 Ma in the northern Norwegian Caledonides: $\mathrm{U}-\mathrm{Pb}$ zircon ages from the Seiland Igneous Province. Geological Magazine 143, 887-903.

Roberts, D., Nordgulen, Ø. \& Melezhik, V.A. 2007: The Uppermost Allochthon in the Scandinavian Caledonides: from a Laurentian ancestry through Taconian orogeny to Scandian crustal growth on Baltica. Geological Society of America Memoir 200, 357-377.

Robins, B. 1982: The geology and petrology of the Rognsund intrusion, West Finnmark, northern Norway. Norges geologiske undersøkelse Bulletin 371, 1-55.

Robins, B. 1996: The Seiland Igneous Province, N. Norway: general geology and magmatic evolution. Field Trip guidebook, Part II, IGCP Project 336. Norges geologiske undersøkelse Report 96.127, 30 pp.

Robins, B. 1998: The mode of emplacement of the Honningsvang Igneous Suite, Magerøya, northern Norway. Geological Magazine 135, 231-244.

Robins, B. \& Gardner, P.M. 1975: The magmatic evolution of the Seiland Province, and Caledonian plate boundaries in northern Norway. Earth and Planetary Science Letters 26, 167-178.

Robins, B., Gading, M., Yurdakul, M. \& Aitcheson, S.J. 1991: The origin of macrorhytmic units in the Lower Zone of the Lille Kufjord Intrusion, northern Norway. Norges geologiske undersøkelse Bulletin $420,13-50$

Rodionov, A. \& Ofstad, F. 2012a: Helicopter-borne magnetic, electromagnetic and radiometric geophysical survey at Vanna, Karlsøy, Troms. Norges geologiske undersøkelse Report 2012.021, $23 \mathrm{pp}$.

Rodionov, A. \& Ofstad, F. 2012b: Helicopter-borne magnetic, electromagnetic and radiometric geophysical survey in Rombaken area, Narvik, Nordland. Norges geologiske undersøkelse Report 2012.022, 25 pp.

Rodionov, A., Koziel, J. \& Lynum, R. 2012a: Helicopter-borne magnetic, electromagnetic and radiometric geophysical survey in Mauken area, Målselv, Troms. Norges geologiske undersøkelse Report 2012.010, $26 \mathrm{pp}$.

Rodionov, A., Ofstad, F. \& Tassis, G. 2012b: Helicopter-borne magnetic, electromagnetic and radiometric geophysical survey in Kvæfjord area, Kvæfjord, Troms. Norges geologiske undersøkelse Report 2012.055, 29 pp.

Rodionov, A., Ofstad, F. \& Tassis, G. 2012c: Helicopter-borne magnetic, electromagnetic and radiometric geophysical survey in Andøya area, Andøya, Nordland. Norges geologiske undersøkelse Report 2012.056, $28 \mathrm{pp}$.

Rodionov, A., Ofstad, F. \& Tassis, G. 2012d: Helicopter-borne magnetic, electromagnetic and radiometric geophysical survey in Finnsnes area, Lenvik, Troms. Norges geologiske undersøkelse Report 2012.047, 28 pp.

Rodionov, A., Ofstad, F., Lynum, R. \& Tassis, G. 2012e: Helicopterborne magnetic, electromagnetic and radiometric geophysical survey in the Alta - Kvænangen area, Troms and Finnmark. Norges geologiske undersøkelse Report 2012.065, 28 pp.

Rodionov, A., Ofstad, F. \& Tassis, G. 2013a: Helicopter-borne magnetic, electromagnetic and radiometric geophysical survey in the western part of Austvågøya, Lofoten archipelago, Nordland. Norges geologiske undersøkelse Report 2013.045, 26 pp.

Rodionov, A., Ofstad, F., Stampolidis, A. \& Tassis, G. 2013b: Helicopterborne magnetic, electromagnetic and radiometric geophysical survey in at Langøya in Vesterålen, Nordland. Norges geologiske undersøkelse Report 2013.044, 26 pp.

Rodionov, A., Ofstad, F., Stampolidis, A. \& Tassis, G. 2013c: Helicopterborne magnetic, electromagnetic and radiometric geophysical survey in the Evenes area. Evenes, Narvik, Skånland and Tjeldsund
Municipalities, Nordland and Troms Counties. Norges geologiske undersøkelse Report 2013.046, 26 pp.

Rodionov, A., Ofstad, F., Stampolidis, A. \& Tassis, G. 2013d: Helicopterborne magnetic, electromagnetic and radiometric geophysical survey in the Øksfjord area, Finmark. Norges geologiske undersøkelse Report 2013.050, 26 pp.

Rodionov, A., Ofstad, F., Stampolidis, A. \& Tassis, G. 2014a: Helicopterborne magnetic, electromagnetic and radiometric geophysical syrvey of Stjernøy, Finnmark County. Norges geologiske undersøkelse Report 2014.033, 24 pp.

Rodionov, A., Ofstad, F., Stampolidis, A. \& Tassis, G. 2014b: Helicopterborne magnetic, electromagnetic and radiometric geophysical survey at Northern Senja in 2012, 2013 and 2014, Troms County. Norges geologiske undersøkelse Report 2014.039, 32 pp.

Rodionov, A., Ofstad, F., Stampolidis, A. \& Tassis, G. 2014c: Helicopterborne magnetic, electromagnetic and radiometric geophysical survey in the Kåfjord area, Troms County. Norges geologiske undersøkelse Report 2014.043,29 pp.

Rodionov, A., Ofstad, F., Stampolidis, A. \& Tassis, G. 2015. Helicopterborne magnetic, electromagnetic and radiometric geophysical survey in Nordreisa, Troms County. Norges geologiske undersøkelse Report 2015.045, 36 pp.

Selbekk, R.S., Furnes, H., Pedersen, R.B. \& Skjerlie, K.P. 1998: Contrasting tonalite genesis in the Lyngen Magmatic Complex, North Norwegian Caledonides. Lithos 42, 243-268.

Selbekk, R.S., Skjerlie, K.P. \& Pedersen, R.B. 2000: Generation of anorthositic magma by $\mathrm{H}_{2} \mathrm{O}$-fluxed anatexis of silicaundersaturated gabbro: an example from the north Norwegian Caledonides. Geological Magazine 137, 609-621.

Siedlecka, A. \& Roberts, D. 1996: Finnmark Fylke. Berggrunnsgeologi, scale 1:500,000, Norges geologiske undersøkelse.

Siedlecka, A., Krill, A.G., Often, M., Sandstad, J.S., Solli, A., Iversen, E. \& Lieungh, B. 1985: Lithostratigraphy and correlation of the Archaean and Early Proterozoic rocks of Finnmarksvidda and the Sørvaranger district. Norges geologiske undersøkelse Bulletin 403, 7-36

Skaar, J.A.A. 2014: 3D geophysical and geological modelling of the Karasjok Greenstone Belt. MSc thesis, Norwegian University of Science and Technology, Trondheim, $170 \mathrm{pp}$.

Skilbrei, J.R., Habrekke, H., Olesen, O., Kihle, O. \& Macnab, R. 1991: Shaded relief aeromagnetic colour map of Norway and the NorwegianGreenland and Barents Seas: Data compilation and examples of interpretation. Norges geologiske undersøkelse Report 91.269, 15 pp.

Slagstad, T., Pin, C., Roberts, D., Kirkland, C.L., Grenne, T., Dunning, G., Sauer, S. \& Andersen, T. 2014: Tectonomagmatic evolution of the Early Ordovician suprasubduction-zone ophiolites of the Trondheim Region, Mid-Norwegian Caledonides. 4 Corfu. F., Gasser, D. \& Chew, D.M. (eds.): New perspectives on the Caledonides of Scandinavia and related areas, Geological Society of London Special Publications 390, 718 pp. 541-561.

Stampolidis, A., Ofstad, F. \& Baranwal, V. 2014: Helicopter-borne magnetic and radiometric geophysical survey at Austvågøya, Hinnøya, Tjeldøya and Hadseløya areas, in Troms and Nordland counties. Norges geologiske undersøkelse Report 2014.007, 36 pp.

Stampolidis, A., Ofstad, F. \& Tassis, G. 2015: Helicopter-borne magnetic and radiometric geophysical survey at Gratangen and Sørreisa, Troms county. Norges geologiske undersøkelse Report 2015.011,29 pp.

Stephens, M.B. \& Gee, D.G. 1989: Terranes and polypase accretionary history in the Scandinavian Caledonides. Geological Society of America Special Paper 230, 17-30.

Sturt, B.A. \& Ramsay, D.M. 1965: The alkaline complex of the Breivikborn area, Sørøy, northern Norway. Norges geologiske undersøkelse 231, $142 \mathrm{pp}$.

Torgersen, E. 2015: Geological investigations of the Repparfjord Tectonic Window, northern Norway. PhD thesis, Norwegian University of Science and Technology, Trondheim, $228 \mathrm{pp}$.

Torgersen, E., Viola, G. \& Sandstad, J.S. 2015: Revised structure and stratigraphy of the northwestern Repparfjord Tectonic Window, 
northern Norway. Norwegian Journal of Geology 95, 397-421.http:// dx.doi.org/10.17850/njg95-3-06.

Verduzco, B., Fairhead, J.D. \& MacKenzie, C. 2004: New insights into magnetic derivatives from structural mapping. The Leading Edge $23,116-119$.

Walker, P. 1991: Helicopter geophysical survey in Finnmark, 1991. Norges geologiske undersøkelse Report 91.256, 12 pp.

Zwaan, K.B. 1988: Geologisk kart over Norge. Berggrunnskart NORDREISA, scale 1:250,000, Norges geologiske undersøkelse.

Zwaan, K.B. 1995: Geology of the West Troms Basement Complex, northern Norway, with emphasis on the Senja Shear Belt: a preliminary account. (Extended abstract). Norges geologiske undersøkelse Bulletin 427, 33-36.

Zwaan, K.B. \& Roberts, D. 1978: Tectonostratigraphic succession and development of the Finnmarkian nappe sequence, North Norway. Norges geologiske undersøkelse 343, 53-71.

Zwaan, K.B. \& van Roermund, H.L.M. 1990: A rift-related mafic dyke swarm in the Corrovarre Nappe of the Caledonian Middle Allochthon, Troms, North Norway, and its tectoometamorphic evolution. Norges geologiske undersøkelse Bulletin 419, 25-44.

Zwaan, K.B., Fareth, E. \& Grogan, P.W. 1998: Geologisk kart over Norge, berggrunnskart TROMS $\varnothing$, scale 1:250,000, Norges geologiske undersøkelse.

Åm, K. 1975: Aeromagnetic basement complex mapping north of latitude $62^{\circ} \mathrm{N}$, Norway. Norges geologiske undersøkelse 316, 351374. 
